\title{
Bacterial Community Composition and Structure in an Urban River Impacted by different Pollutant Sources
}

A. Mark Ibekwe ${ }^{1} *$ Jincai Ma ${ }^{1,2}$, Shelton E. Murinda ${ }^{3}$

${ }^{1}$ USDA-ARS, U.S. Salinity Laboratory, Riverside, CA 92507, USA

${ }^{2}$ Key Laboratory of Groundwater Resources and Environment, Ministry of Education, Jilin University, Changchun 130021, China.

${ }^{3}$ Animal and Veterinary Sciences Department, California State Polytechnic University, Pomona, CA 91768, USA

*Corresponding author:

A. Mark Ibekwe

USDA-ARS-U. S. Salinity Laboratory

450 W. Big Springs Rd

Riverside, CA 92507.

Phone: 951-369-4828

Fax: 951-342-4964

E-mail: Mark.Ibekwe@ars.usda.gov

Short Title: Bacterial Composition in Urban River

Key words: Pyrosequencing, Microbial Diversity, Watershed, Non-Point Source Pollution, Sediment, Surface water. 


\section{ABSTRACT}

25 Microbial communities in terrestrial fresh water are diverse and dynamic in composition due to

26 different environmental factors. The goal of this study was to undertake a comprehensive

27 analysis of bacterial composition along different rivers and creeks and correlate these to land-use

28 practices and pollutant sources. Here we used 454 pyrosequencing to determine the total

29 bacterial community composition, and bacterial communities that are potentially of fecal origin,

30 and of relevance to water quality assessment. The results were analyzed using UniFrac coupled

31 with principal coordinate analysis (PCoA) to compare diversity, abundance, and community

32 composition. Detrended correspondence analysis (DCA) and canonical correspondence analysis

33 (CCA) were used to correlate bacterial composition in streams and creeks to different

34 environmental parameters impacting bacterial communities in the sediment and surface water

35 within the watershed. Bacteria were dominated by the phyla Proteobacteria, Bacteroidetes,

36 Acidobacteria, and Actinobacteria, with Bacteroidetes significantly $(P<0.001)$ higher in all

37 water samples than sediment, where as Acidobacteria and Actinobacteria where significantly

38 higher $(\mathrm{P}<0.05)$ in all the sediment samples than surface water. Overall results, using the $\beta$

39 diversity measures, coupled with PCoA and DCA showed that bacterial composition in sediment

40 and surface water was significantly different $(P<0.001)$. Also, there were differences in

41 bacterial community composition between agricultural runoff and urban runoff based on

42 parsimony tests using 454 pyrosequencing data. Fecal indicator bacteria in surface water along

43 different creeks and channels were significantly correlated with $\mathrm{pH}(P<0.01), \mathrm{NO}_{2}(P<0.03)$,

44 and $\mathrm{NH}_{4} \mathrm{~N}(\mathrm{P}<0.005)$; and in the sediment with $\mathrm{NO}_{3}(P<0.015)$. Our results suggest that

45 microbial community compositions were influenced by several environmental factors, and $\mathrm{pH}$, 
$46 \mathrm{NO}_{2}$, and $\mathrm{NH}_{4}$ were the major environmental factors driving FIB in surface water based on CCA

47 analysis, while $\mathrm{NO}_{3}$ was the only factor in sediment.

48

49

50

51

52

53

54

55

56

57

58

59

60

61

62

63

64

65

66

67

68

\section{Introduction}

Terrestrial fresh water sediment bacterial communities are a major component of microbial food webs, biogeochemical cycles and energy flows in the sediment-water interface of rivers and streams (Ruiz-González et al., 2015). Rivers are the chief source of renewable water for humans and freshwater ecosystems (Vörösmarty et al., 2010), yet microbial diversity in flowing freshwater (lotic) is less commonly studied than in marine or lake ecosystems (Zinger et al., 2012). Their diversity and structure are determined by the temporal and spatial variability of physicochemical and biotic parameters and thus, can reflect local environmental conditions (Urakawa et al., 1999; Zhang et al., 2008a, b). Any shift in nutrient, environmental and pollution profiles in the benthic-pelagic ecosystems will directly influence bacterial communities and that in turn will further affects nutrient cycle and other related communities (Hale et al., 2015).

Therefore, microbial communities in rivers are diverse and dynamic in composition due to environmental stresses and nutrient compositions (Nogales et al., 2007). Furthermore, the composition of a microbial community in a river has been suggested as an indicator for pollution (Atlas, 1984).

Microbial communities in polluted rivers may contain not only broad functional diversities, but also bacteria, which may be pathogenic for humans and livestock. Escherichia coli and enterococci are widely used to monitor fecal contamination in drinking and recreational water. The occurrence of pathogenic bacteria in river water may increase near large urban populations following failure in sewage treatment processes. This is very common in developing countries with inefficient sewage treatment, low income, fast-growing populations and severe 
water stress where infection rates by water-borne pathogens are high (Abraham 2011). The

70 current study was conducted in a large urban watershed with varying land use in southern

71 California with low flowing rivers and creeks. Pollutants in the watershed mainly consist of

72 pathogens and nutrients due to the densely populated areas, some agricultural activities, and

73 urban and storm-water runoff in the region. Different federal, state, and private agencies have

74 monitored fecal bacterial composition from the surface water (Izbicki et al., 2004; Rice, 2005),

75 but no studies have been done to uncover bacterial composition within the water bodies and

76 sediment within the watershed using deep sequencing. Recently, terminal restriction fragment

77 length polymorphism (T-RFLP) and Sanger sequencing were used to describe microbial

78 community structure and composition in low flowing surface water within a small section of the

79 watershed with different sources of pollutants (Ibekwe et al., 2012). During that study, bacterial

80 community structure using T-RFLP showed that bacterial contamination of the low flowing river

81 was not significantly different between concentrated animal feeding operations (CAFOs) and

82 urban runoff. The current study expands on that study by using pyrosequencing to assess

83 bacterial composition in the watershed, and correlate this data with some water chemistry

84 parameters collected during the sampling period. River pollution is not limited to this watershed

85 in southern California according to the United States Environmental Protection Agency (US-

86 EPA), $45 \%$ of streams and rivers, and $32 \%$ of bays and estuaries in the United States are

87 impacted by pathogens and sewage discharge (USEPA, 1986). Therefore, due to the presence of

88 bacterial pollutants in some rivers in the middle Santa Ana River watershed, there is a need for

89 the comprehensive analysis of bacterial composition in water bodies in order to understand their

90 fate and transport. 
In a recent study to better understand ecosystem health, and obtain foundational data to

92 answer fundamental questions about microbial communities in flowing river affected by land

93 use, it was found that sequence composition and average genome size vary with sampling site,

94 environmental conditions, and water chemistry (Van Rossum et al., 2015). Other studies have

95 shown that using taxonomic characterization of riverine bacterial microbiomes, bacterioplankton

96 communities vary by location and nutrient concentrations (Hu et al., 2014; Jackson et al.,

97 2014; Read et al., 2015; Ruiz-González et al., 2015; Savio et al., 2015; Wang et al., 2015), and in

98 a 3-year study focusing on spring and summer,(Fortunato et al., 2013). In this study, we

99 examined the microbial community composition for a year in sediment and surface water with

100 inputs from different rivers and creeks impacted by agricultural activities such as concentrated

101 animal feeding operations (CAFOs), urban runoff, waste water treatment plants (WWTPs), and a

102 combination of these pollutant sources (recreational park) using pyrosequencing. We examined

103 both sediment and surface flow microbial diversity, since sediment community may act as a

104 major source to surface flow microbial community. We also monitored fecal indicator bacteria

105 (FIB) for water quality assessments. Our goal was to identify species richness at the local scales,

106 and differences in diversity across space and time, with an attempt to identifying both extrinsic

107 and intrinsic factors that may explain differences in taxon composition among different

108 communities separated by different sources of pollutants within the watershed. We hypothesized

109 that bacterial diversity decreases with increasing pollutants, reflecting specific environmental

110 factors along different rivers and creeks and land-use practices such as agriculture, urban runoff,

111 and WWTPs. However, due to low water flow volume and concrete lined channels along urban

112 runoff creeks; we expect to find low diversity compared with recreational water outlets. Finally, 
113 other measured chemical and biological variables were correlated to understand the influence of 114 these variables on the fate of indicator bacteria in the watershed.

117 Materials and methods

\section{Study area and sample collection}

We conducted this study in the middle Santa Ana River (MSAR) watershed in the

120 southwestern corner of San Bernardino County and the northwestern corner of Riverside County

121 (Fig. 1) in southern California, USA. The current population of the watershed is 1.9 million

122 people, based upon the 2010 census data. Approximately $32 \%$ of land use in the watershed is

123 residential, commercial or industrial, and with the rest, urban and agriculture. The area contained 124 approximately 385,000 cows in 1995 (RWQCB 2005), and as of January 2009, this number was 125 down to about 138,500 (SAWPA, 2013).

In this study, we expanded our sampling sites from 14 to 20 to include another creek that 127 originates from a lower elevation $(\mathrm{N} 2 ; 207 \mathrm{~m})$ as compared to $\mathrm{N} 1$ that originates from $1447 \mathrm{~m}$ 128 elevation (Ibekwe et al., 2012). The Prado recreational area was also included because surface

129 flow from the some sections of the watershed and empties into this subsection. Sampling 130 locations with site names, descriptions, and global positioning system (GPS) coordinates are

131 listed in Table S1; Fig. 1. Sampling locations were based upon historical data obtained for the 132 Total Maximum Daily Loads (TMDL) for Bacterial Indicators for MSAR watershed (Rice 133 2005), and divided into five zones (Table S1; Figure S1). Zone 1 consist of seven sites (UR2, 
UR3, UR4, UR5, UR9, and UR12, and UR13) along the Chino Creek and Cucamonga creek representing urban runoff; zone 2 has four sites along Cypress channel (CAFO6, CAFO7, CAFO8, and CAFO10) representing agricultural activities; zone 3 consist of four sites (PRADO2, PRADO3, PRADO4, AND PRADO5) around the Prado Recreational Park; zone 4 consist of samples from three waste-water treatment facilities (WW11, WW13, and WW14); and finally zone 5 consist of two natural sites (N1 and N2). Table S1 identifies the "zones" and corresponding sites, along with the number of samples acquired at each site. Water samples were collected from the three waste-water treatment plants (WWTPs) at sampling ports at the end of the plant where it discharges tertiary-level-treated water into Chino Creek. The sites along Chino creek had low flow on concrete lined channels resulting in low bacterial concentrations. Agricultural runoff from CAFOs was the main source of pollutant into Cypress channel while Chino Creek was affected more by WWTPs and urban runoff. The natural sites on Ice House Canyon (N1) and N2 on the lower elevation were used mainly as the control sites, and historical data for fecal coliforms had averaged $9 \mathrm{CFU} 100 \mathrm{~mL}^{-1}$ over a five-year time period, from 2000 to 2005 (Rice 2005). The sites were divided into zones based on pollutant sources. Analysis of covariance (ANOCOVA) model was used to evaluate our primary factors of interest which were pollutant sources or sites and other environmental parameters as additional covariate factors to determine the effects of zonation on our sampling strategy (Ibekwe et al., 2011). During this study, it was shown that total bacterial counts (API) did not significant differ between sites and seasons. It was also shown that the summary statistics for the $\log _{10}$ transformed bacteria concentration models for total coliform (TC), fecal coliform (FC), E. coli, and enterococci based on Shapiro-Wilk (SW) test scores for residual normality were not significantly different between sites along each zone (Ibekwe et al., 2011). The primary goal of this study was to understand and 
157 quantify the spatial-temporal trends in various bacteria measurements along the Chino Creek 158 samples UR2, UR3, UR4, UR5, UR9, and UR12, and UR13 and Cypress Channel samples 159 CAFO6, CAFO7, CAFO8, and CAFO10, and Prado recreational area PRADO2, PRADO3, 160 PRADO4, AND PRADO5, and the natural sites N1 and N2 as baseline control. Towards this 161 goal, these sites were sampled quarterly for a year. Rainfall in the watershed is predominantly between December and April, with a mean 163 annual rainfall of $\leq 800 \mathrm{~mm}$, resulting in a variable base stream flow between seasons as 164 previously described (Ibekwe et al., 2011). Briefly, the United States Geological Survey (USGS) 165 gauged data shows the mean annual stream flow from Chino Creek (UR 3-Chino Creek) was $166133.6 \mathrm{~m}^{3} \mathrm{~s}^{-1}$ ) representing urban runoff and at Cypress channel, representing agricultural runoff 167 (CAFO 6-Cypress channel) was $96.8 \mathrm{~m}^{3} \mathrm{~s}^{-1}$. Furthermore, four water quality parameters were 168 also consistently acquired at each sample point: water $\mathrm{pH}$, salinity, turbidity, and temperature. Water samples were collected using sterile Nalgene sampling bottles and field parameters 170 such as salinity, $\mathrm{pH}$, temperature, turbidity, and dissolved oxygen were taken at each sample 171 location using standard methods (APHA, 1995). All samples were collected in duplicate. For 172 sites that were deep enough to obtain samples, grab samples were collected about $10-15 \mathrm{~cm}$ 173 below the surface of the water. Sites with a shallow flow were sampled using a sterile stainless174 steel sampling device. Sample turbidity was determined using a Hach model 2100P Portable 175 Turbidimeter (Loveland, CO) according to manufacturer's instructions and calibrated each day 176 of use. Salinity and $\mathrm{pH}$ were recorded with a standard conductivity/pH meter. Concentrations of 177 fecal indicator bacteria were determined within six hours of sample collection according to 178 Standard Methods 9222B for total coliform, EPA Methods 1600 for Enterococcus and 1603 for 179 E. coli (USEPA, 1986), based on membrane filtration. 
Sediment samples from the 0 - 15-cm depth were taken from the creek or river banks using 197 1998).

ethanol-disinfected core tubes and stored in Whirl-Pak bags at $4{ }^{\circ} \mathrm{C}$ until processed; usually within $24 \mathrm{~h}$. Samples were transported to the laboratory for analysis in coolers maintained between $2^{\circ}-10^{\circ} \mathrm{C}$ using ice packs. Total nitrogen (TN) and organic $\mathrm{N}$ were determined using Flash 2000 NC Analyzers (Thermo Scientific, MA). Salinity (EC, dS m ${ }^{-1}$ ) of each soil was obtained by determining the conductivity of soil water extract (30 min extraction in horizontal shaker with water to soil ratio of 1:1, vol: wt) using a conductivity meter (Okaton, IL).

Concentrations (mM) of $\mathrm{Na}^{+}, \mathrm{K}^{+}, \mathrm{Ca}^{2+}, \mathrm{Mg}^{2+}, \mathrm{P}$, and $\mathrm{S}$ in soil water extracts was determined using an Optima-3300 DV ICP-OES spectrometer (Perkin-Elmer, MA) that was calibrated with certified standards prior to sample analysis. Fecal indicator bacteria (Enterococcus and E. coli) in sediment samples (10 g) were determined using serial dilution method in a 1:9 sediment PBS ratio. In brief, $90 \mathrm{~mL}$ of phosphate buffered saline (PBS) water (0.0425 g/L KH $\mathrm{KH}_{4}$ and $0 \cdot 4055$ $\mathrm{g} / \mathrm{L} \mathrm{MgCl}_{2}$ ) was added to sediment and shaken for 15 minutes. Ten $\mathrm{mL}$ of the suspension was added to Colilert or Enterolert vessel, diluted 1:10 and mixed. One $\mathrm{mL}$ from the 1:10 dilution was transferred to another vessel and was further diluted 1:1,000, and an aliquot was added to the media, mixed, then sealed in QuantiTrays and incubated at $37^{\circ} \mathrm{C}$ for $24 \mathrm{~h}$. Samples were processed following the manufacturer's protocol in accordance with method 9223 (Eaton et al.,

\section{DNA extraction and purification from sediment and water samples}

Total bacterial DNA was extracted from $500 \mathrm{mg}$ of sediment samples and from water sample from the different sites. DNA was extracted using Power Soil and Water DNA kits (MO BIO, Inc., Solana Beach, CA), according to the manufacturer's protocol. Extracted DNA $(2 \mu \mathrm{L})$ 
was quantified using a Nanodrop ND-1000 spectrophotometer (Nanodrop Technologies, Wilmington DE), and run on $1.0 \%$ agarose gel before used for pyrosequencing.

\section{Pyrosequencing}

Sediment and water DNA samples were submitted to Core for Applied Genomics and Ecology at the University of Nebraska Lincoln for PCR optimization and pyrosequencing analysis. The V1V2 region of the 16S rRNA gene was amplified using bar-coded fusion primers with the Roche454 A or B titanium sequencing adapters (in italics), followed by a unique 8-base barcode sequence (B) and finally the $5^{\prime}$ ends of primer A-8FM (5'-

\section{CCATCTCATCCCTGCGTGTCTCCGACTCAGBBBBBBBBAGAGTTTGATCMTGGCTCA}

\section{G) and of primer B-357R (5'-CCTATCCCCTGTGTGCCTT-GGCAGTCTCA GBBBBBBBB}

CTGCTGCCTYCCGTA-3' (Benson et al., 2010). All PCR reactions were quality-controlled for amplicon saturation by gel electrophoresis; band intensity was quantified against standards using GeneTools software (Syngene). The resulting products were quantified using PicoGreen (Invitrogen, Carlsbad, CA) and a Qubit fluorometer (Invitrogen) before sequencing using Roche454 GS FLX titanium chemistry (Benson et al., 2010; Wu et al., 2010). Raw data were treated with the Pyrosequencing Pipeline Initial Process (Cole et al., 2009) of the Ribosomal Database Project (RDP) to match barcodes and to trim off the adapters, barcodes and primers using the default parameters, and to remove sequences containing ambiguous ' $N$ ' or shorter than $200 \mathrm{bps}$ (Claesson et al., 2009). These raw reads were further denoised to remove sequences that are likely due to pyrosequencing errors (Huse et al., 2010; Roeselers et al., 2011), and chimeras were filtered out using Chimera Slayer (Haas et al., 2011). Bacterial pyrosequencing population data were further analyzed by performing multiple sequence alignment techniques using the dist.seqs 
224 function in MOTHUR, version 1.9.1(Schloss et al., 2009). MOTHUR was also used to assign

225 sequences to operational taxonomic units (OTUs, 97\% similarity) and calculate both Shannon's

226 diversity index values $\left(\mathrm{H}^{\prime}\right)$, and Chao richness estimates. Taxonomic classification of the

227 bacterial sequences of each sample was carried out individually, using the RDP Classifier. A

228 bootstrap cutoff of $80 \%$ suggested by the RDP was applied to assign the sequences to different

229 taxonomic levels. The sequence data sets of potential human pathogen (461 sequences) from our

230 previously study using the same sites had been deposited in Sequence read Archive under the

231 project name SRP028870 (Ibekwe et al., 2013), with accession numbers SRX335804 to

232 SRX335812 (http://www.ncbi.nlm.nih.gov/Traces/sra/sra.cgi?study=SRP028870). The new

233 dataset used for this study was based on 12959 16S rRNA sequence tags generated through 454

234 pyrosequencing.

\section{Statistics and analysis of pyrosequencing data}

236 Analysis of variance (ANOVA) model using both site and field parameter classifications were

237 used as the statistical model for analyzing the (log-transformed) density of indicator bacteria

238 from the watershed (Ibekwe et al., 2011). Along with total coliforms, E. coli, and enterococci

239 densities, four additional field parameters, i.e., $\mathrm{pH}$, salinity (EC), turbidity, and surface water

240 temperature for each sampling point were measured. Variations in each of these water quality

241 parameters are known to affect bacterial concentrations. Principal coordinates analysis (PCoA)

242 and hierarchical clustering in UniFrac were carried out using MOTHUR. PCoA was conducted

243 based on RDP Classifier results from MOTHUR, OTUs, and weighted UniFrac (Hamady et al.,

244 2010). The relaxed neighbor-joining algorithm in Clearcut (version 1.0.9) (Sheneman et al.,

245 2006), was used to construct phylogenetic trees for between-site comparisons as previously

246 described (Ibekwe et al., 2011) and parsimony tests in Treeclimber (Schloss and Handelsman, 
247 2006). Pairwise comparisons with Bonferonni correction (Neter, 1996; Hollister et al., 2010) was

248 used to test significant differences $(P \leq 0.001)$. Additional statistics were performed on

249 pyrosequencing data on the relative percentage of each operational taxonomic unit (OTU), or the

250 sum of OTUs at a specific taxonomic (phylum, class, order, or family) level. The microbial

251 diversity indices were analyzed using the vegan package of R software version 3.1.0 (The $\mathrm{R}$

252 foundation for Statistical Computing: http://www.r-project.org/). Detrended correspondence

253 analysis (DCA) was employed to determine the overall structural changes in the microbial

254 communities by R software version v3.1.0. DCA is an ordination technique that uses detrending

255 to remove the arch effect, where the data points are organized in a horseshoe-like shape, in

256 correspondence analysis (Zhou et al., 2012). Canonical correspondence analysis (CCA) was

257 performed to determine the most significant sediment and water variables shaping microbial

258 community composition and structure. The Mantel test $(p<0.001)$ was used to select the most

259 significant environmental variables and to examine the correlation between community structure

260 or fecal indicator bacteria and these variables (Zhou et al., 2012). Using automatic forward

261 selection in CCA, 11 environmental variables were selected for analysis in sediment and 10 in

262 water, and these include $\mathrm{EC}, \mathrm{pH}, \mathrm{NO}_{2}, \mathrm{NO}_{3}, \mathrm{NH}_{4} \mathrm{~N}, \mathrm{CA}, \mathrm{Mg}, \mathrm{Na}, \mathrm{K}, \mathrm{P}, \mathrm{S}$. CCA was performed

263 using the vegan package in R. During the analysis matrices of pollutant sources or sample units

264 (the five zones) versus bacterial OTUs were paired with matrices of samples units versus

265 environmental variables from sediments and surface water for CCA.

266 Results

267 Environmental variables 
268 Physical and chemical characteristics, such as temperature, turbidity, salinity, dissolved oxygen

269 (DO), and $\mathrm{pH}$ were determined in various surface water and sediment samples retrieved from the

270 different sites. Salinity (EC), pH, temperature, turbidity, DO, $\mathrm{NO}_{3}, \mathrm{NO}_{2}, \mathrm{NH}_{4}, \mathrm{Ca}, \mathrm{Na}, \mathrm{Mg}, \mathrm{P}, \mathrm{S}$,

271 and $\mathrm{K}$ are summarized in Table S2. The temperature values for surface water samples and

272 wastewater effluent stream ranged from $6{ }^{\circ} \mathrm{C}$ at Ice House Canyon (S1) to $23^{\circ} \mathrm{C}$ at WWTP

273 (S14). Average turbidity values were below 1 nephelometric turbidity units (NTU) for the natural

274 site at Ice House Canyon (N1). The basic univariate summary statistics for the three indicator

275 bacteria measurements of interest; i.e., TC, E. coli, and enterococci counts are shown in Figure 2.

276 The statistics summarized the natural log transformed counts for each of these response

277 variables. Indicator bacterial counts were not significantly different between sites in sediment

278 samples (Fig. 2A) and in water samples (Fig. 2B) within each zone. However, FIB counts were

279 significantly different $(P<0.023)$ between zones. Examination of each site throughout the

280 watershed indicated that fecal bacterial concentrations along urban runoff creeks and CAFO

281 channel routinely exceeded the applicable water quality objectives for E. coli (235 CFU/100 mL)

282 except in the natural site (N1) and WWTPs.

\section{Community composition, diversity, and estimated richness}

284 A total of 12959 16S rRNA sequence tags were generated through 454 pyrosequencing, with an 285 average read length of about 200 bp (Table S3). The 454 sequence libraries ranged in size from

286142 sequence tags (smallest) at water samples from urban runoff to 5666 sequences at the natural

287 site surface water (largest) and contained between 68 OTUs in water samples to 1770 OTUs in

288 natural site sediment (Table S3; Fig. S2A\&B). All data were normalized to the smallest sequence

289 tag, and the data reanalyzed to show normal distribution of variances (Table 1). Shannon

290 diversity index values $\left(\mathrm{H}^{\prime}\right)$ suggest that diversity varied along the study zones, with the lowest 
291 diversity associated with urban runoff water. Diversity values decreased significantly $(P<0.05)$

292 between water and sediment materials collected from urban runoff, agricultural runoff, and

293 control sites. Although we determined hundreds and thousands of tags per sample, rarefaction

294 curves of OTUs were far from the plateau, indicating that there were more undetermined tags

295 either from real rare species or artificial sequences produced by PCR and sequencing errors (Fig

296 S2A\&B). Chao richness estimates suggest that higher sequences were captured in sediment than

297 in surface water. Both the Shannon's diversity index value at a sequencing depth of 142 (Table 1)

298 and its rarefaction curves showed that the sediment had the highest diversity, ranging from 5.82

299 (natural site) to 5.32 (Prado park), while the water samples had the lowest, ranging from 4.93

300 (Prado park) to 4.17 (urban runoff), and there were significant differences $(P<0.05)$ among the

301 three groups. Summary statistics of the non-normalized data showed that higher OTUs, Chao

302 richness, and Shannon diversity index values $\left(\mathrm{H}^{\prime}\right)$ were also higher in sediment than in surface

303 water (Table S3). Therefore, all analyses were done on both datasets to see if there are

304 differences in the grouping pattern of bacterial community structures. However, most of the data

305 presented are from the normalized dataset, with few exceptions involving sequence library.

306 Furthermore, Figure S1 shows the physical appearances of sampling locations from the different

307 zones, including zone 1 from urban runoff samples, obtained mainly from concrete lined

308 channels. These channels have very low volume of water flowing with continuous exposure to

309 ultraviolet radiation, resulting in low sequence tag (142). The 454 libraries detected 24 bacterial

310 phyla from the non-normalized dataset with Proteobacteria (34.8\%) and Bacteroidetes $(18.70 \%)$

311 encountered most frequently (Table 2; Fig. S3). The community in the sediment was the most

312 evenly distributed, while surface water samples were the most skewed with a dominance

313 of Proteobacteria (Table 2). Two phyla (Proteobacteria and Bacteroidetes) dominated (>50\%) 
314 bacterial communities of sediment and surface water from the nine potential sources of

315 contaminants classified using RDP Classifier at a confidence threshold of $80 \%$. The two phyla

316 were followed by a few other major (average abundance $>1 \%$ in at least two sources) phyla,

317 including Actinobacteria (3.79\%), Acidobacteria (2.99\%), Verrucomicrobia (4.02\%),

318 Chloroflexi (1.45\%), Planctomycetes (2.54\%), Firmicutes (2.41\%), and Gemmatimonadetes

$319(2.54 \%)$. A few phyla with minor abundance $(<1 \%)$ in one of the 9 sources were also determined

320 (Table 2). Within Proteobacteria, Epsilonproteobacteria only occurred at very low levels (0.00-

$3211.67 \%$, averaging 0.19\%) (Table S4). The Beta-subdivision on the average was the most

322 dominant Proteobacteria, followed by Gamma, Delta, and Alphaproteobacteria. However,

323 Gammaproteobacteria was the dominant class of Proteobacteria in surface water from all the

324 sources, and Delta and Alphaproteobacteria were in the sediment except in the natural sites for

325 Alphaproteobacteria.

326 Phylogenetic structure of bacterial community from different zones

Phylogenetic structures of microbial communities, as indicated by detrended

correspondence analysis (DCA)-based ordination revealed that the phylogenetic community

329 structures were significantly different between water and sediment samples (Fig. 3 A). Further

analysis showed pollutant sources correlated with factors influencing bacterial assemblages $\left(\mathrm{R}^{2}=\right.$

$0.32, P<0.001)$ since bacteria grouped according to the sources of pollutants such as CAFOs or urban runoff. Samples from the different sources on the distribution of bacterial similarity were sorted into different groups such as CAFO or urban runoff by applying principal coordinates analysis (PCoA), and the UPGMA hierarchical clustering analysis to a matrix of UniFrac distances using the UniFrac web interface in MOTHUR. The PCoA (Fig. 3B) showed that microbial community structure were significantly different $(P=0.001)$ between water samples 
337 from urban runoff (zone 1) and CAFOs (Cypress channel-zone 2). These samples clustered to the

338 middle portion of Figure 3B. This result was different from our previous study using T-RFLP

339 that suggested no significant differences between CAFO runoff and urban runoff (Ibekwe et al.,

340 2012). Furthermore, samples from WWTPs clustered to the bottom right, while sample from

341 Prado region (zone 3) clustered to the far left, and those from the natural sites clustered at the top

342 (zone 5), and these were significantly different $(P<0.05)$. Microbial community structure in

343 sediment samples were also analyzed using the same procedure (Fig. 3 C). Parsimony tests

344 confirmed that community structures of the four sources were significantly different from each

345 other $(\mathrm{P}<0.001)$, with urban, $\mathrm{CAFO}$, and natural sites clustering on PCoA 1 and Prado samples

346 on PCoA 2. Hierarchical clustering analysis (Fig. 3D) with Jackknife supporting values using

347 both water and sediment samples showed that microbial community structure from the five zones

348 were significantly different from each other when sediment and water samples were analyzed

349 together.

Canonical correspondence analysis (CCA) was performed to determine the most

351 significant water and sediment variables shaping microbial community composition and

352 structure. CCA showed that microbial community structure was significantly shaped by several

353 key physical and chemical variables for water (Fig. 4A), such as $\mathrm{NO}_{2}, \mathrm{pH}$, and $\mathrm{NO}_{3}$. The biplot

354 score showed $30.5 \%$ of the variations were explained by CCA 1 while 28.6 were explained by

$355 \mathrm{CCA} 2$. In the sediment (Fig. $4 \mathrm{~B}), \mathrm{NO}_{3}(\mathrm{P}<0.015)$ was the strongest environmental variable

356 contributing to the biplot. In the sediment $35.9 \%$ of the variations were explained by CCA1,

357 while by $32.0 \%$ of the variations were explained by CCA2.

358

359 Correlation of environmental variables with fecal indicator bacterial populations 
CCA was performed to determine the most significant water and sediment variables shaping 361 fecal indicator bacterial population in the watershed. The Mantel test was used to examine the 362 correlation between fecal indicator bacteria population and each variable (Fig.5). CCA of fecal

363 indicator bacterial data and water variables showed that indicator bacterial population were 364 significantly shaped by several key environmental factors (Fig. $5 \mathrm{~A})$ : $\mathrm{pH}(F=4.69, p<0.01), \mathrm{NO}_{2}$

$365(F=2.85, p<0.03)$, and $\mathrm{NH}_{3} \mathrm{~N}(F=8.77, p<0.005)$, with $13.6 \%$ of the constrained variance 366 explained by CCA1 and $4.8 \%$ by CCA2. However, in the sediment the effects of environmental 367 factors were not as strong as in the water column (Fig. 5B), with $8.73 \%$ of the constrained 368 variance explained by CCA1 and $5.46 \%$ by CCA2. Fecal indicator bacterial population were 369 significantly shaped by $\mathrm{NO}_{3}(F=3.05, p<0.015)$.

371 Potential bacterial community sequence richness for fecal pollution assessment

372 The assessment of some potential bacterial community sequence relative richness for FIB across 373 the different pollutant sources are presented in Table 3. The top phyla with the highest degree of 374 relative richness associated with fecal pollution were Proteobacteria, Firmicutes, Actinobacteria, 375 Bacteroidetes, and Spirochaetes. Proteobacterial sequences dominated our sample with more 376 than $40 \%$ OTUs on the average from each source (Table 3). Proteobacteria contributed the 377 highest proportion of bacterial richness that may be associated with fecal sources that could 378 cause diseases in humans (Table 3). Some of the potential sequence tags were associated with 379 sequences from Arcobacter, Citrobacter, Shigella, Aeromonas, and Legionella and were detected 380 in all the sources except urban runoff. The next dominant phylum was the Actinobacteria, and 381 the sequences at the genus level were dominated by Nocardia, Corynebacterium and 382 Mycobacterium. Another phylum with a major contribution of bacterial communities that may be 
associated with fecal sources was Bacteroidetes. Bacteroides was the dominant genus from this

384 phylum (Table 3), with the highest percent richness in sediment from Prado recreational water.

385 The Phylum Fermicutes produced a very diverse group of bacteria of fecal origin that may be

386 very important for water quality assessment. These include Bacillus, Staphylococcus and

387 Clostridium (Table 3), with Bacillus dominating CAFO runoff sediment, natural site sediment

388 and WWTP, and with Clostridium in Prado park recreational area sediment and natural site

389 sediment.

390

\section{DISCUSSION}

391 In this study, we employed high-throughput 454 pyrosequencing techniques to quantify bacterial 392 community structures in a large urban watershed impacted by many pollutant sources such as 3

393 WWTPs, large developing urban population of about 1.9 million, and a dwindling cow

394 population. Within our samples, the natural sites showed the highest bacterial richness and

395 diversity, while urban runoff was the lowest both in the sediment and surface water. It should be 396 noted that the natural sites were not influenced by pollutants because the water source was

397 dominated mostly by melting snow and FIB from the natural sites as previously shown to be less 398 than 9.0 CFU/ $\mathrm{ml}$ (Ibekwe et al. 2011). The main reason for the low bacterial diversity in urban 399 runoff could be that the river flows mainly through a concrete channel (Fig.S1), and about $90 \%$ 400 of the flow are from tertiary treated waste water. Furthermore, the volume of flow during the dry 401 season (April -August) may be less than $20 \mathrm{~cm}$ deep, resulting in continuous exposure to ultra402 violet radiation. Also, sediment samples were localized deposits of soil particles on the concrete 403 channel. Therefore, the sediment and water samples from the concrete lines were subjected to 404 extreme conditions during dry weather. During the wet season (November -March) the volume 405 of flow may triple or even higher depending on the amount of rainfall, but are still subjected to 
the same extreme weather conditions. These data were consistent with recent sediment bacterial community analyses results of pyrosequencing data from urban areas affected by WWTPs showing bacterial communities significantly decreased in population and diversity (Drury et al., 409 2013) due to the influence of treated waste water. In our results, the Chao index from the natural 410 sites sediment and surface water were significantly higher than all other sites with the non411 normalized data (Table S3), although richness estimators may be extremely sensitive to the error412 prone sequences (Quince et al., 2009; Reeder and Knight, 2009). However, the Shannon's

413 diversity index which is less sensitive to sequencing and PCR errors (Wang et al., 2012) showed 414 the highest diversity in the natural site sediment using both the normalized and the non415 normalized data (Table 1 and Table S3).

416 Our work in this watershed has produced results that are very similar to results produced 417 from other large/urban rivers in Chicago (Drury et al., 2013). Here we examined the quality of 418 the river water about $75 \mathrm{~km}$ from the ocean and observed that FIB were higher than the state and 419 EPA standards (Fig. 2). The high numbers may be associated with nitrogen sources of nutrients 420 as they correlate significantly with FIB from upstream (Fig. 5A). This is not surprising, because 421 urban areas have the potential to pollute water in many ways as this may contain pollutants such 422 as fecal coliform bacteria, nitrates, phosphorus, chemicals, and other bacteria. Therefore, 423 preventing pollution in the middle Santa Ana river watershed may help reduce pollutants 424 entering Pacific Ocean.

425 Our study showed that microbial communities in sediment were significantly different 426 from microbial communities in surface water (Fig. 3A) as the water samples clustered together 427 and away from sediments. Microbial communities in surface waters are highly responsive to 428 perturbation, dissolved organic matter concentration, and chemical stress among others (Bodtker 
429 et al., 2008; Wassel and Mills 1983; Nelson, 2009; Hirayama et al., 2005). The detection of

430 diverse community composition and structure within the different zones of the watershed

431 suggests changes in environmental microbial communities in surface waters are highly

432 responsive to changes environmental factors such as nutrients, salinity (EC), and pH (Fig.4

$433 \mathrm{~B} \& \mathrm{C})$. For instance microbial communities were quite different between the natural sites and

434 urban runoff as well as the other zones. The main drivers may be differences in nutrients and

435 salinity from the urban area that may be influenced by household waste (Table S2), whereas

436 microbial communities from agricultural area may be influenced by excess nutrients impacted by

437 concentrated animal feeding operations (CAFOs). Nutrients from the different zones may enrich

438 different bacterial populations depending on their sources into the Santa Ana River. For instance,

439 fast unifrac analysis showed that the populations of river water were quite different among the

440 five zones (Fig. 3B).

441 The order Bacteroidales is enriched within the gut microbiota of many mammals (Dowd

442 et al., 2008; Cotta and Fooster, 2006; Ishii et al., 2006; Fogarty and Voytek, 2005; Juteau et al.,

443 2005), and specific species within this order have been proposed as fecal indicators (Weary et al.,

444 2008). Sequences of the genus Bacteroides was commonly identify in the recreational water

445 samples from Prado Park (Table 4). Some species from this genus has been identified as

446 indicators of fecal pollution originating from mammalian sources (Savichtcheva et al., 2007;

447 Savichtcheva and Okabe 2006). Bacteroides, have a high degree of host specificity that reflects

448 differences in the digestive system of the host animal (Bernhart and Field, 2000) and have a

449 small potential to grow in the environment (Kreader, 1998) thus making it a good indicator of

450 recent fecal contamination. The members of this phylum contain diverse bacterial species that

451 have colonized virtually all types of habitats. They are among the major members of the 
452 microbiota of animals, especially in the gastrointestinal tract, and are frequently used for

453 microbial source tracking (Dubinsky et al., 2012; Li et al., 2015; Gomi et al., 2014). The

454 presence of DNA sequences in surface water in Prado recreational area may suggest some recent

455 fecal contamination close to sampling. Another group of bacteria that are commonly used as

456 indicator bacteria are the Enterococcus. Although we were able to grow pure cultures from the

457 genus (Fig. 2A and B), the pyrosequencing method could not detect their DNA sequences

458 suggesting that this technique may have some limitations when it comes to detecting less

459 abundant members of the community (Table S4). It was also interesting to note that other fecal

460 indicator bacterial DNA sequences, such as Clostridia, were found mainly in sediment samples

461 associated with recreational water sediment at Prado recreational area and in the sediment of

462 natural sites. This indicates the wide distribution of Clostridia DNA in sediment samples more

463 than surface water and suggests that the sediment may be a major source of this class of bacteria

464 (Weary et al., 2008). The high prevalence of Enterobacteriales DNA sequences in Table S4 falls

465 in line with the high FIB counts observed in Figures 2A\&B. Again, DNA sequences belonging to

466 the genus Escherichia and Salmonella were not detected with this method, but Shigella DNA

467 sequences were identified in surface water from agricultural runoff and in the sediment from

468 natural sites.

469 Conclusions

470 Our data showed that $\mathrm{pH}, \mathrm{NO}_{2}$, and $\mathrm{NH}_{4}$ were the major environmental factors correlating 471 significantly with FIB sequences in urban river runoff water based on CCA analysis, while $\mathrm{NO}_{3}$

472 was the only factor in sediment. Using pyrosequencing, we were able to understand some of the

473 relationships between microbial community structures, nutrient, and environmental factors in a

474 large watershed as they relate to changes in microbial communities from different sources. It 
475 shows that microbial communities in the sediment-water interface in terrestrial fresh water with

476 low flow were significant reduced in composition due to different environmental factors. The

477 reduction was the highest from urban sources in comparison to CAFO and recreational sources.

478 The higher level of bacterial composition in the CAFO and recreational sources was due to

479 higher sediment nutrient availability to surface water in these zones.

480

481 Acknowledgements

482 This research was supported by the 214 Manure and Byproduct Utilization Project of the USDA-

483 ARS. We thank Damon Baptista for technical assistance. Mention of trademark or proprietary

484 products in this manuscript does not constitute a guarantee or warranty of the product by the

485 USDA and does not imply its approval to the exclusion of other products that may also be

486 suitable.

487

$488 \quad$ References

489 Abraham, W-R., 2011. Megacities as sources for pathogenic bacteria in rivers and their fate

490 downstream. Int. J. Microbiol. 798292.

491 American Public Health Association. 1995. Standard methods for the examination of

492 the examination of water and wastewater. $19^{\text {th }}$ ed. Am. Public Health Asso. Washington,

$493 \quad$ DC. 
Atlas, R., 1984.Use of microbial diversity measurements to assess environmental stress. in Current Perspectives in Microbial Ecology, M. J. Klug and C. A. Reddy, Eds., pp. 540545, American Society for Microbiology, Washington, DC, USA.

Benson, A.K., Kelly, S.A., Legge, R., Ma, F., Low, S. et al. 2010. Individuality in gut microbiota composition is a complex polygenic trait shaped by multiple environmental and host genetic factors. PNAS. 107, 18933-18938.

Bernhard, A.E., Field, K.G., 2000. A PCR assay to discriminate human and ruminant feces on the basis of host differences in Bacteroides-Prevotella genes encoding 16S rRNA. Appl. Environ. Microbiol. 66, 4571-4574. doi:10.1128/AEM.66.10.4571-4574.2000.

Bodtker, G., Thorstenson, T., Lillebo, B.L., Thorbjornsen, B.E., Ulvoen, R.H., et al. 2008. The effect of long-term nitrate treatment on SRB activity, corrosion rate and bacterial community composition in offshore water injection systems. J. Ind. Microbiol Biotechnol. 35, 1625-1636. doi: 10.1007/s10295-008-0406-x.

Claesson, M., O’Sullivan, O., Wang, Q., Nikkila, J., Marchesi, J., Smidt, H. et al. 2009. Comparative analysis of pyrosequencing and a phylogenetic microarray for exploring microbial community structures in the human distal intestine. PloS One 4: e6669.

Cole, J.R., Wang, Q., Cardenas, E., Fish, J., Chai, B., Farris, R.J, et al. 2009. The Ribosomal Database Project: improved alignments and new tools for rRNA analysis. Nucleic Acids Res. 37, D141-D145.

Cotta, M., Forster, R., 2006. The family Lachnospiraceae, including the genera Butyrivibrio, Lachnospira and Roseburia. In: Dworkin M, Schleifer K-H, Rosenberg E, Falkow S, 
editors. The Prokaryotes - A handbook on the biology of Bacteria: Bacteria:

Firmicutes, Cyanobacteria. 3 ed. New York, NY: Springer-Verlag New York, LLC. pp. $1002-1021$

Dowd, S.E., Callaway, T.R., Wolcott, R.D., Sun, Y., McKeehan, T., et al. 2008. Evaluation of the bacterial diversity in the feces of cattle using $16 \mathrm{~S}$ rDNA bacterial tag-encoded FLX amplicon pyrosequencing (bTEFAP). BMC Microbiol 8: doi: 10.1007/bf02015128.

Drury, B., Rosi-Marshall, E., and Kelly, J.J., 2013. Wastewater treatment effluent reduces the abundance and diversity of benthic bacterial communities in urban and suburban rivers. Appl. Environ. Microbiol. 79, 1897-1905.

Dubinsky, E. A., Esmaili, L., Hulls, J., Cao, Y., Griffith, J., Andersen, G. L. 2012. Application of phylogenetic microarray analysis to discriminate sources of fecal pollution. Environ. Sci. Technol. 46, 4340-4347.

Eaton, A.D.; Clesceri, L.S.; Greenberg, A.E.; Franson, M.A.H. 1998. Standard Method for Examination of Water and Wastewater; American Public Health Association: Washington, DC, USA.

Fogarty, L.R., and Voytek, M.A., 2005. Comparison of Bacteroides-Prevotella 16S rRNA genetic markers for fecal samples from different animal species. Appl. Environ. Microbiol. 71, 5999-6007.

Fortunato, C.S., Eiler, A.,Herfort,L.,Needoba,J.A.,Peterson,T.D., and Crump, B.C. 2013. 
Determining indicator taxa across spatial and seasonal gradients in the Columbia river coastal margin. ISMEJ. 7, 1899-1911.doi: 10.1038/ismej.2013.79

Gomi, R.; Matsuda, T.; Matsui, Y.; Yoneda, M. 2014. Fecal source tracking in water by nextgeneration sequencing technologies using host-specific Escherichia coli genetic markers. Environ. Sci. Technol. 48, 9616- 9623.

Haas, B.J, Gevers, D., Earl, A.M., Feldgarden, M., Ward, D.V., et al 2011. Chimeric 16S rRNA sequence formation and detection in Sanger and 454-pyrosequenced PCR amplicons. Genome Res. 21, 494-504.

Hale, R. L., Turnbull, L., Earl, S. R., Childers, D. L., and Grimm, N. B. 2015. Stormwater infrastructure controls runoff and dissolved material export from arid urban watersheds. Ecosystems 18, 62-75. doi: 10.1007/s10021-014-9812-2

Hamady, M., Lozupone, C., Knight, R. 2010. Fast UniFrac: facilitating high-throughput phylogenetic analyses of microbial communities including analysis of pyrosequencing and PhyloChip data. ISME J. 4, 17-27.

Hirayama, H., Takai, K., Inagaki, F., Yamato, Y., Suzuki, M, et al. 2005. Bacterial community shift along a subsurface geothermal water stream in a Japanese gold mine. Extremophiles 9, 169-184.

Hollister, E.B., Engledow, A.S., Hammet, A.J., Provin, T.L., Wilkinson, H.H., et al. 2010. Shifts in microbial community structure along an ecological gradient of hypersaline soils and sediments. ISME J. 4, 829-838. 
561

562

563

564

Hu, A., Yang, X., Chen, N., Hou, L., Ma, Y., Yu, C.-P. 2014. Response of bacterial communities to environmental changes in a mesoscale subtropical watershed, Southeast China. Sci. Total Environ. 472746-756. 10.1016/j.scitotenv.2013.11.097

Huse, S.M., Welch, D.M., Morrison, H.G., Sogin, M.L,. 2010. Ironing out the wrinkles in the rare biosphere through improved OTU clustering. Environ Microbiol 12: 1889-1898.

Ibekwe, A.M., Lesch, S.M., Bold, R.M., Leddy, M.B., Graves, A.K., 2011. Variations of indicator bacteria in a large urban watershed. Transactions of the ASABE. 54, 22272236.

Ibekwe, A.M., Leddy, M., Bold, R.M., Graves, A.K. 2012. Bacterial community composition in low-flowing river water with different sources of pollutants. FEMS Microbiol. Ecol. 79, 155-166.

Ibekwe, A.M., Leddy, M., Murinda, S.E., 2013. Potential human pathogenic bacteria in a mixed urban watershed as revealed by pyrosequencing. PLoS ONE 8; e79490. doi:10.1371/journal.pone.0079490.

Ishii, S., Ksoll, W.B., Hicks, R.E, Sadowsky, M.J., 2006. Presence and growth of naturalized Escherichia coli in temperate soils from lake superior watersheds. Appl. Environ. Microbiol. 72, 612-621.

Izbicki, JA., Pimentel, M.I., Leddy, M.B., 2004. Microbial and dissolved organic 
carbon characterization of stormflow in the Santa Ana River at Imperial Highway, Southern California, 1999-2002. U.S. Geological Survey, Scientific Investigation Report 2002; 2004-5116.

Jackson, C. R., Millar, J. J., Payne J. T., Ochs, C. A., 2014. Free-living and particle-associated bacterioplankton in large rivers of the Mississippi River Basin demonstrate biogeographic patterns. Appl. Environ. Microbiol. 80, 7186-7195. 10.1128/AEM.01844-14

Juteau, P., Tremblay, D., Villemur, R., Bisaillon, J.G., Beaudet, R. 2005. Analysis of the bacterial community inhabiting an aerobic thermophilic sequencing batch reactor (ATSBR) treating swine waste. Appl. Microbiol. Biotechnol. 66, 115-122.

Kreader, C.A., 1998. Persistence of PCR-detectable Bacteroides distasonis from human feces in river water . Appl. Environ. Microbiol. 64: 4103-105.

\section{Li,X.,Harwood,V.J.,Nayak,B.,Staley,C.,Sadowsky,M.J.,andWeidhaas,J., 2015. A novel} microbial source tracking microarray for pathogen detection and fecal source identification in environmental systems. Environ. Sci. Technol. 49, 73197329.doi:10.1021/acs.est.5b00980

Nelson, C.E., 2009. Phenology of high-elevation pelagic bacteria: the roles of meteorologic variability, catchment inputs and thermal stratification in structuring communities. ISME J. 3, 13-30. doi: 10.1038/ismej.2008.81.

Neter, J ., 1996. Applied Linear Regression Models, 3rd edn. Irwin: Chicago, IL, xv, 720 pp. 
Nogales, B.M., Ma, M., Aguiló-Ferretjans, C., Martín-Cardona, J., Lalucat, J., et al. 2007. Bacterial diversity, composition and dynamics in and around recreational coastal areas. Environ. Microbiol. 9, 1913-1929.

Quince, C., Lanzén, A., Curtis, T.P., Davenport, R.J., Hall, N., et al. 2009. Accurate determination of microbial diversity from 454 pyrosequencing data. Nat. Methods. 6 , 639-641.

Read D. S., Gweon H. S., Bowes M. J., Newbold L. K., Field D., Bailey M. J., et al. 2015.Catchment-scale biogeography of riverine bacterioplankton. ISME J. 9 516-526. 10.1038/ismej.2014.166

Reeder. J., Knight, R., 2009. The 'rare biosphere': a reality check. Nat. Methods. 6,636-637.

Rice, W., 2005. Staff Report on Bacterial Indicator Total Maximum Daily Loads in the Middle Santa Ana River Watershed. Santa Ana Regional Water Control Board, Santa Ana, CA.

Roeselers, G., Mittge, E.K., Stephens, W.Z., Parichy, D.M., Cavanaugh, C.M., Guillemin, K. et al. 2011. Evidence for a core gut microbiota in the zebrafish. ISME J. 5, 1595-1608.

Ruiz-González, C., Niño-García, J. P., Del Giorgio, P. A. 2015. Terrestrial origin of bacterial communities in complex boreal freshwater networks. Ecol. Lett. 18 1198-1206. 10.1111/ele.12499.

RWQCB, Regional Water Quality Control Board. 2005. Resolution amending the water quality control plans for the Santa Ana River Basin to incorporate bacterial indicator total maximum daily loads (TMDLs) for middle Santa Ana River Watershed Water bodies. Regional Board Resolution R8-2005-0001. 
615 Savichtcheva, O., Okayama, N., Okabe, S., 2007. Relationships between Bacteroides 16S rRNA 616 genetic markers and presence of bacterial enteric pathogens and conventional fecal indicators. Water Res. 41, 3615-3628.

618 Savichtcheva, O., Okabe, S., 2006. Alternative indicators of fecal pollution: Relations with

619

620

621

622

623

624

625

626

627

628

629

630

631

632

pathogens and conventional indicators, current methodologies for direct pathogen monitoring and future application perspectives. Water Res. 40, 2463-2476.

Savio, D., Sinclair, L., Ijaz, U. Z., Parajka, J., Reischer, G. H., Stadler, P., et al. 2015. Bacterial diversity along a $2600 \mathrm{~km}$ river continuum. Environ. Microbiol [Epub ahead of print].10.1111/1462-2920.12886

SAWPA: Santa Ana Watershed Project Authority. 2013. Middle Santa Ana River bacterial indicator TMDL 2013 Dry Season Report. Prepared by CDM Smith on behalf of SAWPA and the Middle Santa Ana River Watershed TMDL Task Force. July.

Schloss, P.D., Westcott, S.L., Ryabin, T., Hall, J.R., Hartmann, M., et al. 2009. Introducing mothur: open-source, platform-independent, community-supported software for describing and comparing microbial communities. Appl. Environ. Microbiol.75: 75377541.

Schloss, P.D., Handelsman, J., 2006. Introducing treeclimber, a test to compare microbial community structures. Appl. Environ. Microbiol. 72, 2379-2384. 
633 Sheneman, L., Evans, J., Foster, J.A., 2006. Clearcut: a fast implementation of relaxed neighbor 634 joining. Bioinformatics 22, 2823-2824.

635

USEPA 1986. Ambient Water Quality Criteria for Bacteria - 1986. EPA Office of

636

Water, Washington, DC. EPA 440/5-84-002.

637 Urakawa, H., Tsukamoto, K. K., Ohwada, K., 1999. Microbial diversity in marine sediment from 638

639 Sagami Bay and Tokoyo Bay, Japan, as determined by 16S rRNA gene analysis. Microbiol. 145, 3305-3315.

640

Van Rossum, T., Peabody, M.A., Uyaguari-Diaz, M.I., Cronin, K.I., Chan, M., Slobodan, J.R.,

641 Nesbitt, M.J., Suttle, C.A., Hsiao, W.W.L., Tang, P.K.C., Prystajecky, N.A., Brinkman

642 F.S.L., 2015. Year-Long Metagenomic Study of River Microbiomes Across Land Use

643 and Water Quality. Front. Microbiol. 6:1405. doi: 10.3389/fmicb.2015.01405.

644 Vörösmarty, C. J., McIntyre, P. B., Gessner, M. O., Dudgeon, D., Prusevich, A., Green, P., et al. 645 2010.Global threats to human water security and river biodiversity. Nature. 467 555-561.

646 10.1038/nature09440.

647 Wang, Y., Yang, J., Liu, L., Yu, Z. 2015. Quantifying the effects of geographical and 648 environmental factors on distribution of stream bacterioplankton within nature reserves of 649 Fujian. China. Environ. Sci. Pollut. Res. 22, 11010-11021. 10.1007/s11356-015-4308-y 
650

651

652

653

654

655

656

657

658

659

660

661

662

663

664

665

666

667

668

669

670

Wang, Y., Sheng, H-F., He, Y., Wu, J-Y., Jiang, Y-X., et al. 2012. Comparison of the levels of bacterial diversity in freshwater, intertidal wetland, and marine sediments by using millions of illumina tags. Appl. Environ. Microbiol. 78: 8264-8271.

Wassel, RA., Mills, A.L., 1983. Changes in water and sediment bacterial community structure in a lake receiving acid-mine drainage. Microbial Ecol. 9, 155-169. doi:10.1007/bf02015128.

Weary, N., Lhoutellier, C., Ducray, F., Delgenes, J. P., Godon, J. J. 2008. Behaviour of pathogenic and indicator bacteria during urban wastewater treatment and sludge composting, as revealed by quantitative PCR. Water Res. 42, 53-62.

Wu, G.D., Lewis, J. D., Hoffmann, C., Chen, Y-Y., Knight, R. et al., 2010. Sampling and pyrosequencing methods for characterizing bacterial communities in the human gut using 16S sequence tags. BMC Microbiology. 10, 206.

Zinger, L., Gobet, A., Pommier, T. 2012. Two decades of describing the unseen majority of aquatic microbial diversity. Mol. Ecol. 21, 1878-1896. 10.1111/j.1365294X.2011.05362.x

Zhang, R., Thiyagarajan, V., Qian, P.Y., 2008a. Evaluation of terminal-restriction fragment length polymorphism analysis in contrasting marine environments. FEMS Microbial. Ecology. 65, 169-178.

Zhang, W., Ki, J.S., Qian, P.Y., 2008b. Microbial diversity in polluted harbor sediments: I. Bacterial community assessment based on four clone libraries of 16s rDNA. Estuarine Coastal and Shelf Science. 76, 668-681. 
671 Zhou, J., Xue, K., Xie, J., Deng, Y., Wu, L., et al. 2012. Microbial mediation of carbon-cycle

672 feedbacks to climate warming. Nature Climate Change. 2, 106-110:

673 doi:10.1038/nclimate1331.

674

675 
677

678

679

680

681

682

683

684

685

686

687

688

689

690

691

692

693

694

695

696

697

698

699

700

701

702

703

704

705

706

707

708

709

710

711

712

713

714

Figure 1. Various sampling points along Chino creek and Cypress channel within the middle Santa Ana River (MSAR) watershed. Water flow from the natural site at Ice house Canyon (S1) to the San Antonio creek and into Chino creek. This flows into the Prado basin and into Santa Ana River and finally empties into the Pacific Ocean. The Santa Ana River is critical for the replenishment of Orange County's Groundwater Basin since over 2 million residents in Orange County depend on groundwater for $75 \%$ of their water supply.

Figure 2. Univariate summary statistics for bacterial counts using Shipiro-Wilk test for residual normality for total coliforms, E. coli, and enterococci. (A) Sediment samples (B) water samples. Error bars represent standard errors of duplicate samples pooled throughout each source. Zone 1 consist of urban runoff (UR) and represents seven sites (UR2, UR3, UR4, UR5, UR9, and UR12, and UR13) along the Chino Creek and Cucamonga creek representing; zone 2 has four sites along Cypress channel (CAFO6, CAFO7, CAFO8, and CAFO10) representing agricultural activities; zone 3 consist of four sites ( PRADO2, PRADO3, PRADO4, AND PRADO5) around the Prado Recreational Park; zone 4 consist of samples from three waste-water treatment facilities (WW11, WW13, and WW14); and finally zone 5 consist of two natural sites (N1 and N2). Table S1 identifies the "zones" and corresponding sites, along with the number of samples acquired at each site.

Figure 3. Detrended correspondence analysis (DCA) of bacterial community structure data showing that sediment and river water samples were significantly separated on DCA1 based on bacterial community composition (3A). Principal coordinate analysis (PCoA) obtained using the UniFrac distance matrix comparing the five sources of pollutants. Principal coordinate 1 (P1) vs principal coordinate $2(\mathrm{P} 2)$ are represented. Samples are from pyrosequencing to a matrix of UniFrac distances using the UniFrac web interface in MOTHUR. The PCoA (Fig. 3B) showed samples from urban runoff (Chino creek) and CAFO runoff (Cypress channel) clustering to the middle portion while samples from WWTPs clustered to the bottom right and Prado clustered to the far left and the natural site to the top. Microbial community structure in sediment samples were also analyzed using the same procedure (Fig. 3 C). Cluster analysis of normalized jackknife (1000 permutations) of pyrosequencing data (3D) from both sediment and water samples from all the sampling points throughout the watershed.

Figure 4. Canonical correspondence analysis (CCA) of bacterial community structure of the most significant water and sediment variables shaping microbial community composition and structure. Canonical correspondence analysis (CCA) showed that microbial community structure were significantly shaped by several key physical and chemical variables for water (Fig. 4A), such as electrical conductivity (EC), $\mathrm{NO}_{3}, \mathrm{NO}_{2}$, and $\mathrm{pH}$; and for sediment (Fig. 4B) such as EC, $\mathrm{pH}$, and $\mathrm{NO}_{2}$. 
715 Figure 5. Canonical correspondence analysis (CCA) was performed to determine the most 716 significant water and sediment variables shaping fecal indicator bacterial composition in the 717 watershed. CCA of fecal indicator bacterial data and water variables showed that indicator 718 bacterial composition were significantly shaped by $\mathrm{pH}, \mathrm{NO}_{2}$, and $\mathrm{NH}_{3} \mathrm{~N}$ (Fig. $5 \mathrm{~A}$ ): In the 719 sediment the effects of environmental factors were not as strong as in the water column (Fig. 720 5B). Fecal indicator bacterial composition and structure were significantly shaped by $\mathrm{NO}_{3}$. The 721 Mantel test was used to examine the correlation between fecal indicator bacteria and each 722 variable.

723

724

725 
726 Table 1. Normalized summary of sequence library, OTUs, and diversity and richness estimates at $72797 \%$ level

\begin{tabular}{llllllll}
\hline Group* & Nseqs+ & OTUs & chao & invsimpson & npshannon & simpson & coverage \\
\hline CAFO S & 142 & 113 & 641.11 & 154.01 & 5.73 & 0.006 & 0.309 \\
CAFO W & 142 & 73 & 167.23 & 42.24 & 4.39 & 0.023 & 0.647 \\
UR S & 142 & 104 & 289.88 & 161.46 & 5.38 & 0.006 & 0.435 \\
UR W & 142 & 68 & 162.09 & 19.59 & 4.17 & 0.051 & 0.676 \\
N S & 142 & 115 & 440.71 & 270.56 & 5.82 & 0.003 & 0.323 \\
N W & 142 & 75 & 139.47 & 30.71 & 4.44 & 0.032 & 0.647 \\
Prado S & 142 & 102 & 278.64 & 130.01 & 5.32 & 0.007 & 0.450 \\
Prado W & 142 & 90 & 220.20 & 103.21 & 4.93 & 0.009 & 0.556 \\
WWTPs & 142 & 76 & 186.50 & 30.06 & 4.45 & 0.033 & 0.634
\end{tabular}

*CAFO S = Agricultural runoff sediment, CAFO W = Agricultural runoff water, UR S = Urban runoff sediment, UR W = Urban runoff water, $\mathrm{N} \mathrm{S}=$ Natural site sediment, $\mathrm{N} \mathrm{W}=$ Natural site water, Prado $\mathrm{S}=$ Prado sediment, Prado W. = Prado water, WWTPs = Waste water treatment

731 plant.

$732+$ Nseqs $=$ number of sequence tags, OTUs $=$ Operational taxonomic units. 
Table 2. Santa Ana River percent sample counts by phylum. The abundance is presented in terms 738 of percentage in total bacterial sequences in a sample, classified using RDP Classifier at a 739 confidence threshold of $50 \%$.

\begin{tabular}{|c|c|c|c|c|c|c|c|c|c|c|}
\hline Phyla & Total & $\begin{array}{c}\text { CAFO } \\
\text { S* }^{*}\end{array}$ & $\begin{array}{c}\text { CAFO } \\
\text { W }\end{array}$ & $\begin{array}{c}\text { UR. } \\
\text { S }\end{array}$ & $\begin{array}{l}\text { UR } \\
\text { W }\end{array}$ & $\begin{array}{c}\text { Natural. Site. } \\
\text { S }\end{array}$ & $\begin{array}{c}\text { Natural Site. } \\
\text { W }\end{array}$ & $\begin{array}{l}\text { Prado } \\
\text { S }\end{array}$ & $\begin{array}{c}\text { Prado } \\
\text { W }\end{array}$ & $\begin{array}{l}\text { WWT } \\
\text { P }\end{array}$ \\
\hline Acidobacteria & 2.99 & 4.05 & 0.45 & 4.00 & 0.00 & 4.41 & 0.68 & 2.24 & 0.35 & 0.76 \\
\hline Actinobacteria & 3.79 & 9.54 & 1.35 & 4.80 & 0.00 & 4.81 & 1.90 & 2.75 & 4.59 & 1.53 \\
\hline Armatimonadetes & 0.55 & 0.58 & 0.00 & 0.00 & 0.00 & 0.52 & 0.41 & 0.52 & 1.06 & 0.00 \\
\hline Bacteroidetes & 18.7 & 11.2 & 32.43 & 6.40 & 51.67 & 14.55 & 28.86 & 13.94 & 27.21 & 42.75 \\
\hline $\mathrm{BRC} 1$ & 0.03 & 0.00 & 0.00 & 0.00 & 0.00 & 0.06 & 0.00 & 0.00 & 0.00 & 0.00 \\
\hline Chlorobi & 0.26 & 0.00 & 0.00 & 2.40 & 0.00 & 0.23 & 0.00 & 0.17 & 0.35 & 0.00 \\
\hline Chloroflexi & 1.45 & 1.73 & 0.00 & 0.00 & 0.00 & 1.39 & 0.27 & 4.65 & 0.00 & 0.76 \\
\hline $\begin{array}{l}\text { Deinococcus- } \\
\text { Thermus }\end{array}$ & 0.16 & 0.00 & 0.00 & 0.80 & 1.67 & 0.12 & 0.14 & 0.00 & 0.00 & 0.00 \\
\hline Firmicutes & 2.41 & 3.47 & 1.35 & 0.80 & 0.00 & 2.32 & 1.90 & 3.96 & 1.06 & 1.91 \\
\hline Fusobacteria & 0.10 & 0.00 & 0.00 & 0.80 & 0.00 & 0.12 & 0.14 & 0.34 & 0.35 & 0.00 \\
\hline Gemmatimonadetes & 0.35 & 0.87 & 0.00 & 0.00 & 0.00 & 0.52 & 0.54 & 0.34 & 0.00 & 0.00 \\
\hline Lentisphaerae & 0.06 & 0.00 & 0.00 & 0.00 & 0.00 & 0.00 & 0.27 & 0.00 & 0.00 & 0.00 \\
\hline Nitrospira & 0.16 & 0.87 & 0.45 & 0.80 & 0.00 & 0.23 & 0.14 & 0.34 & 0.00 & 0.00 \\
\hline OD1 & 0.55 & 0.58 & 0.00 & 0.80 & 1.67 & 0.35 & $0.81 \%$ & 0.52 & 1.41 & 1.15 \\
\hline OP11 & 0.03 & 0.29 & 0.00 & 0.00 & 0.00 & 0.00 & $0.00 \%$ & 0.00 & 0.00 & 0.00 \\
\hline Planctomycetes & 2.54 & 1.45 & 0.45 & 0.80 & 0.00 & 3.25 & 1.08 & 2.07 & 0.71 & 0.38 \\
\hline Proteobacteria & 34.8 & 39.3 & 44.59 & 50.40 & 41.67 & 36.17 & 42.28 & 41.14 & 42.05 & 30.92 \\
\hline Spirochaetes & 0.42 & 1.16 & 0.45 & 0.00 & 0.00 & 0.41 & 0.41 & 0.86 & 0.35 & 0.38 \\
\hline SR1 & 0.10 & 0.00 & 0.00 & 0.00 & 0.00 & 0.00 & 0.27 & 0.00 & 0.00 & 0.38 \\
\hline Synergistetes & 0.03 & 0.00 & 0.00 & 0.00 & 0.00 & 0.00 & 0.00 & 0.17 & 0.00 & 0.00 \\
\hline Tenericutes & 0.06 & 0.00 & 0.00 & 0.00 & 0.00 & 0.06 & 0.14 & 0.00 & 0.00 & 0.00 \\
\hline TM7 & 0.51 & 0.29 & 0.00 & 0.80 & 0.00 & 0.87 & 0.41 & 0.52 & 0.00 & 0.00 \\
\hline unclassified & 25.5 & 20.2 & 16.67 & 23.20 & 3.33 & 23.88 & 16.26 & 21.69 & 15.55 & 16.03 \\
\hline Verrucomicrobia & 4.02 & 4.34 & 1.80 & 2.40 & 0.00 & 5.39 & 3.12 & 3.44 & 4.59 & 3.05 \\
\hline WS3 & 0.29 & 0.00 & 0.00 & 0.80 & 0.00 & 0.35 & 0.00 & 0.34 & 0.35 & 0.00 \\
\hline
\end{tabular}

*CAFO S = Agricultural runoff sediment, CAFO W = Agricultural runoff water, UR S = Urban runoff sediment, UR W = Urban runoff water, $\mathrm{N} \mathrm{S}=$ Natural site sediment, $\mathrm{N} \mathrm{W}=$ Natural site water, Prado $\mathrm{S}=$ Prado sediment, Prado W. = Prado water, WWTPs = Waste water treatment plant. 
749 Table 3. Percent of potential bacterial pathogen sequences at the genus level that may be of

750 concern to the assessment of water quality.

\begin{tabular}{|c|c|c|c|c|c|c|c|c|c|c|}
\hline Phyllum & Genus & $\begin{array}{c}\text { CAFO } \\
\mathrm{S}^{*}\end{array}$ & $\begin{array}{l}\text { CAF } \\
\text { O W }\end{array}$ & UR. S & UR W & $\begin{array}{c}\text { Natural. } \\
\text { Site. S }\end{array}$ & $\begin{array}{c}\text { Natural Site. } \\
\text { W }\end{array}$ & $\begin{array}{c}\text { Prado } \\
\text { S }\end{array}$ & $\begin{array}{c}\text { Prado } \\
\text { W }\end{array}$ & WWTP \\
\hline \multirow[t]{3}{*}{ Actinobacteria } & Nocardia & 0 & 0 & 0 & 0 & 0.012 & 0 & 0 & 0 & 0 \\
\hline & Corynebacterium & 0 & 0 & 0 & 0 & 0.012 & 0.022 & 0 & 0 & 0 \\
\hline & Mycobacterium & 0.2144 & 0 & 0 & 0 & 0.122 & 0.011 & 0 & 0 & 0 \\
\hline Bacteroidetes & Bacteroides & 0 & 0 & 0 & 0 & 0 & 0 & 0 & 0.123 & 0 \\
\hline \multirow{5}{*}{ Proteobacteria } & Arcobacter & 0.4287 & 0.360 & 0 & 0.4545 & 0.036 & 0.123 & 0.329 & 0 & 0.068 \\
\hline & Citrobacter & 0 & 0 & 0 & 0 & 0 & 0 & 0.188 & 0 & 0 \\
\hline & Shigella & 0 & 0.072 & 0 & 0 & 0.012 & 0 & 0 & 0 & 0 \\
\hline & Aeromonas & 0 & 0.432 & 0 & 0.0136 & 0.305 & 0.653 & 0.047 & $\begin{array}{l}0.0013 \\
4\end{array}$ & 0 \\
\hline & Legionella & 0 & 0 & 0 & 0 & 0.024 & 0.022 & 0 & 0 & 0 \\
\hline Spirochaetes & Leptospira & 0 & 0.144 & 0 & 0 & 0 & 0.056 & 0 & 0 & 0 \\
\hline \multirow[t]{3}{*}{ Firmicutes } & Bacillus cereus & 1.9293 & 0 & 0 & 0 & 0.195 & 0 & 0 & 0 & 0.068 \\
\hline & Staphylococcus & 0 & 0 & 0 & 0 & 0 & 0.022 & 0 & 0 & 0 \\
\hline & Clostridium & 0 & 0 & 0 & 0 & 0.171 & 0 & 0.094 & 0 & 0 \\
\hline
\end{tabular}

**CAFO S = Agricultural runoff sediment, CAFO W = Agricultural runoff water, UR S = Urban

752 runoff sediment, UR W = Urban runoff water, N S = Natural site sediment, N W = Natural site

753 water, Prado S = Prado sediment, Prado W. = Prado water, WWTPs = Waste water treatment

754 plant.

755

756 


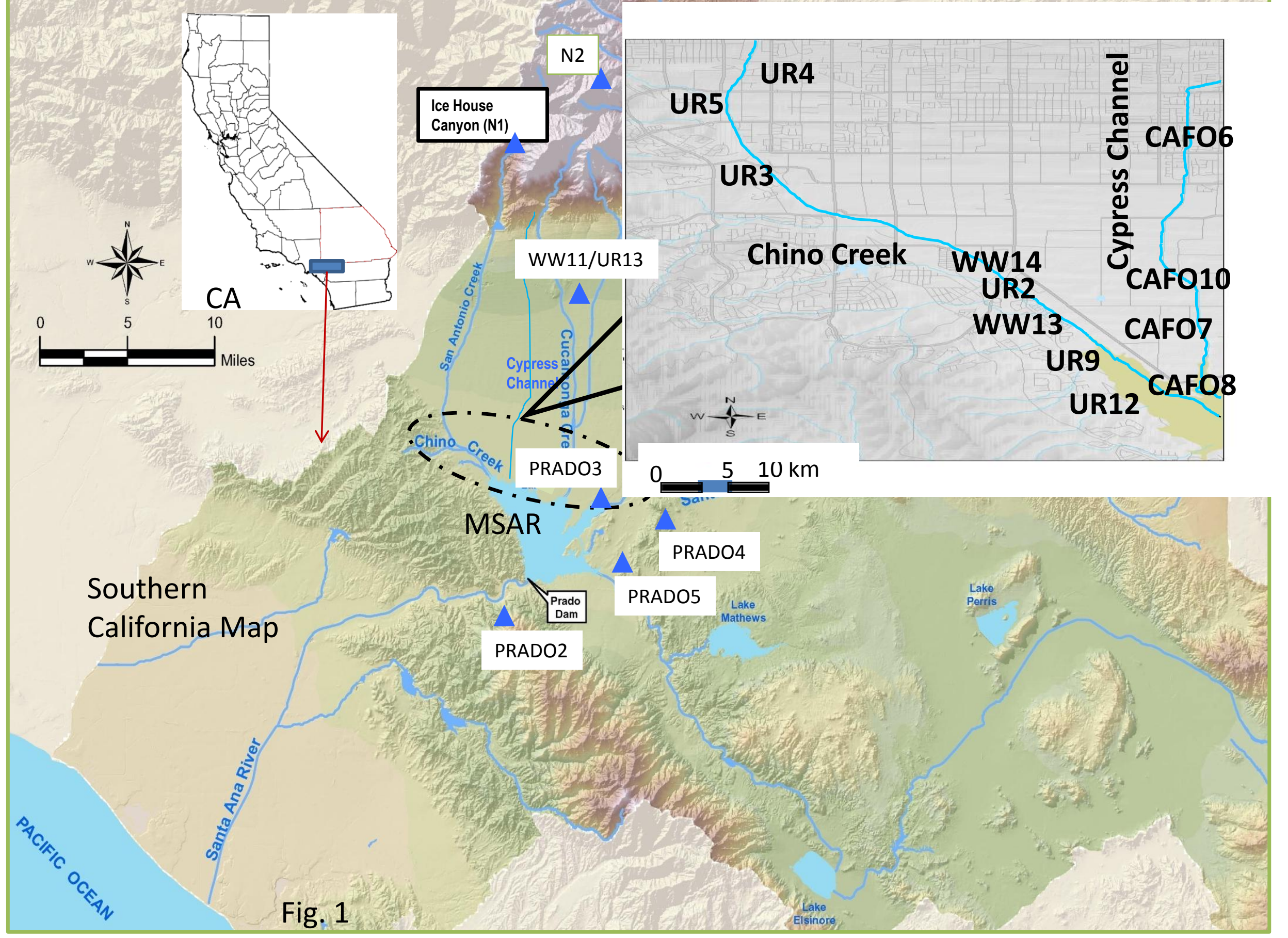




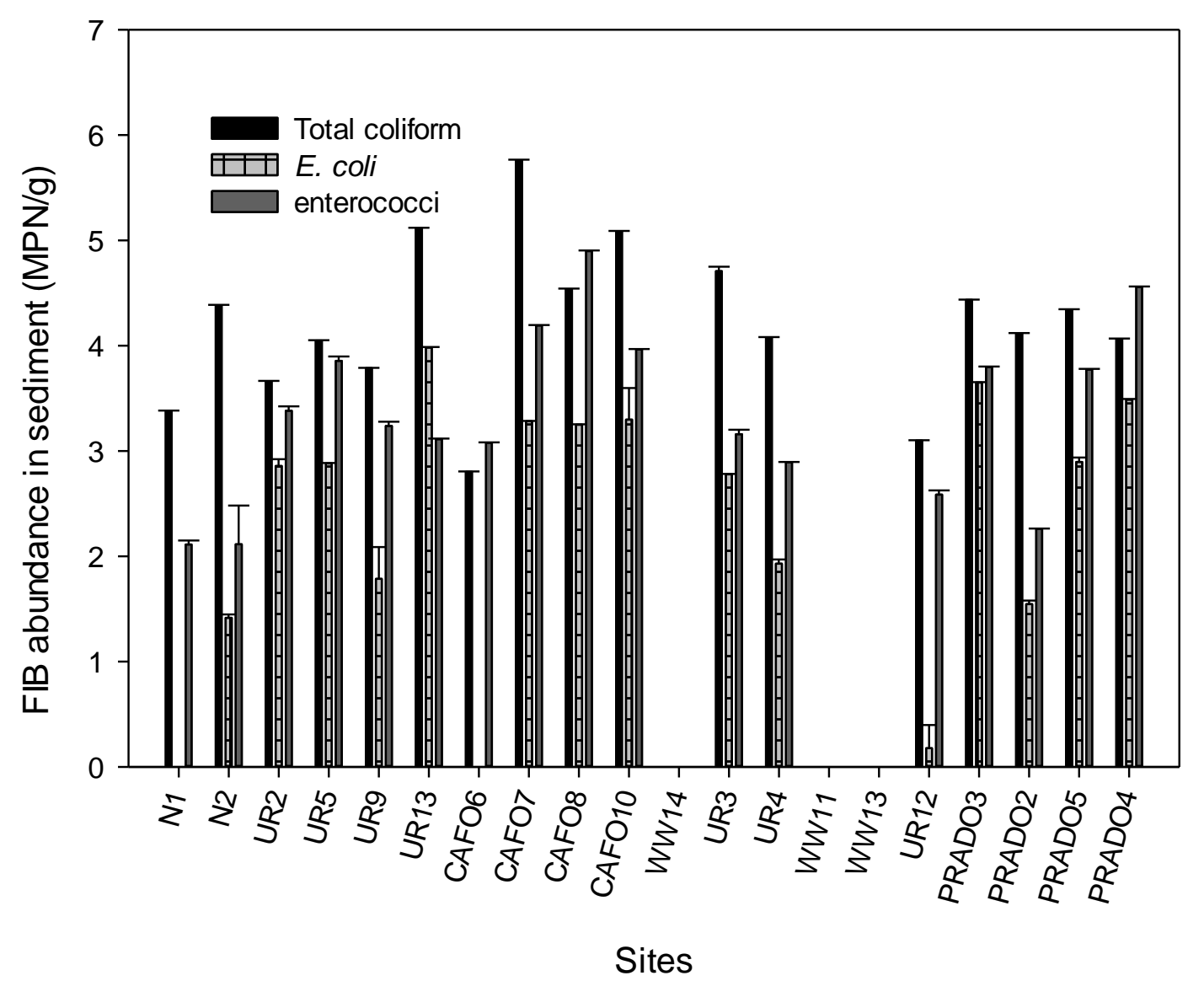

Fig.2A sediment 


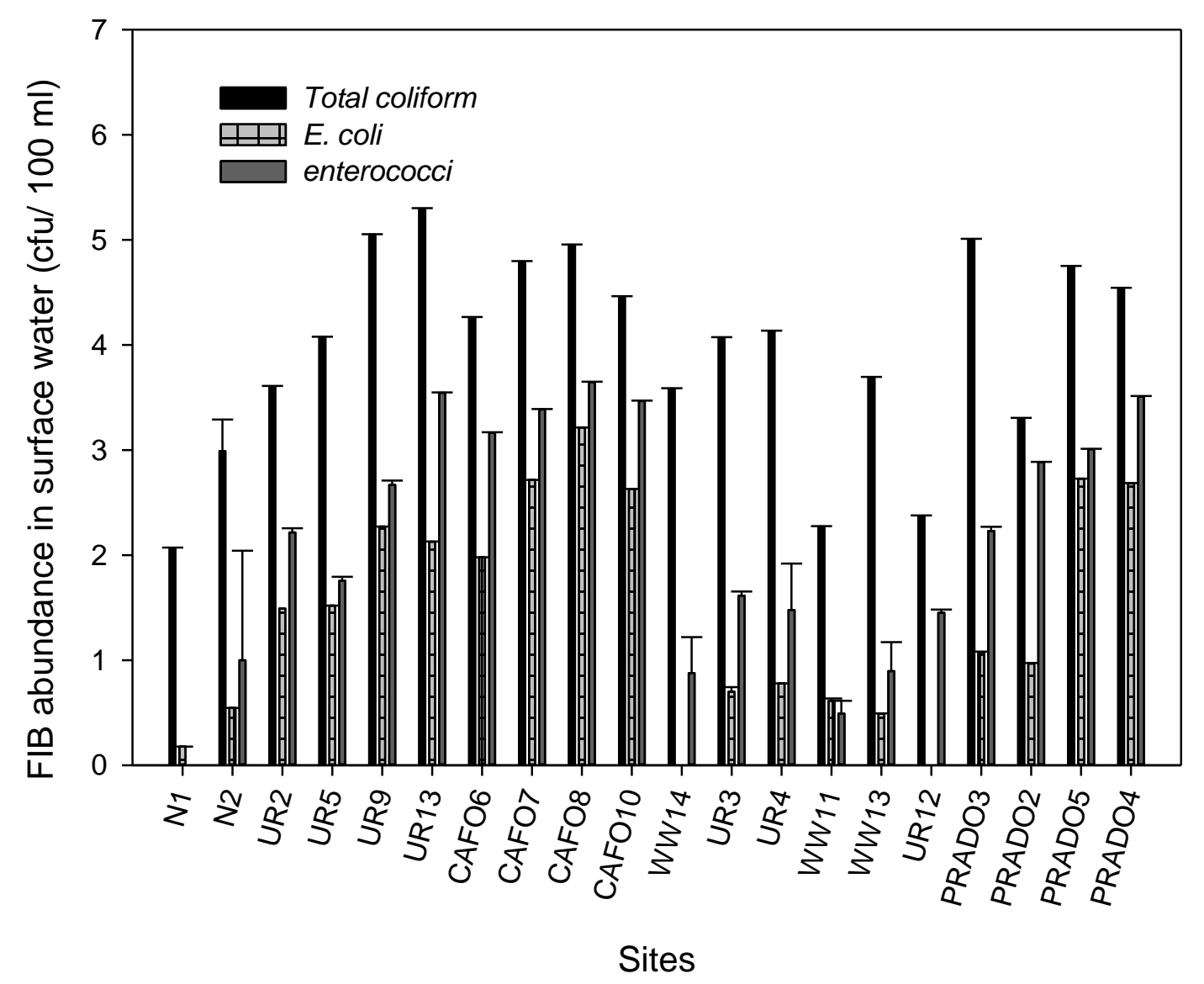

Fig. 2 B. surface water 


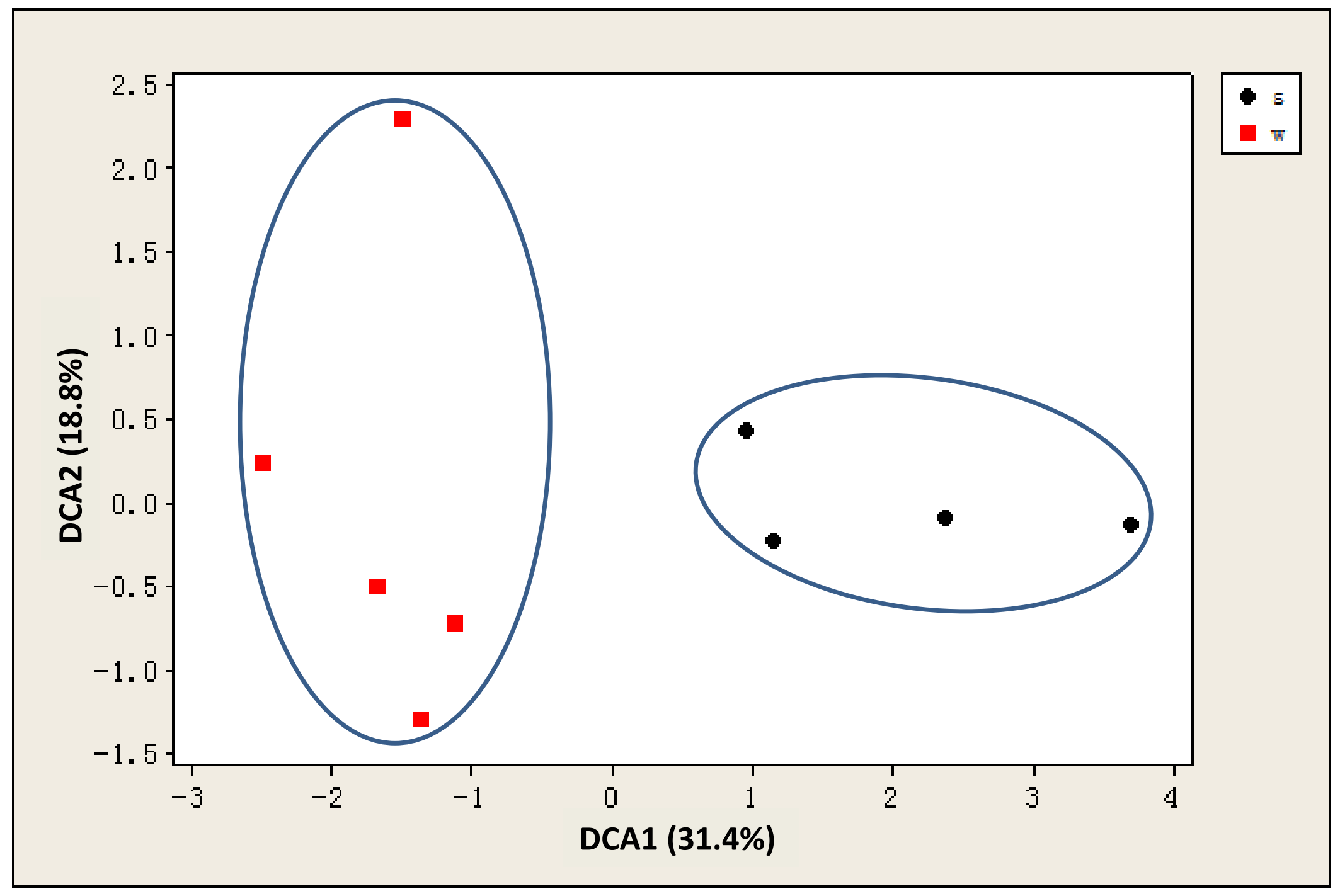

Fig. 3A. 


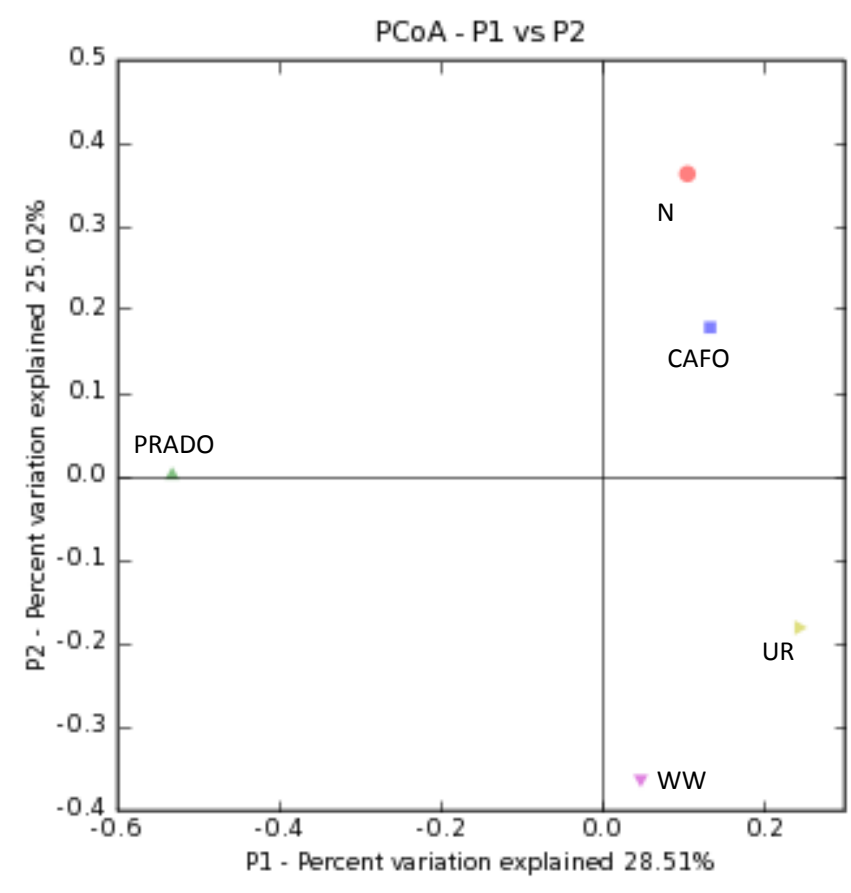

Fig. 3B Water 


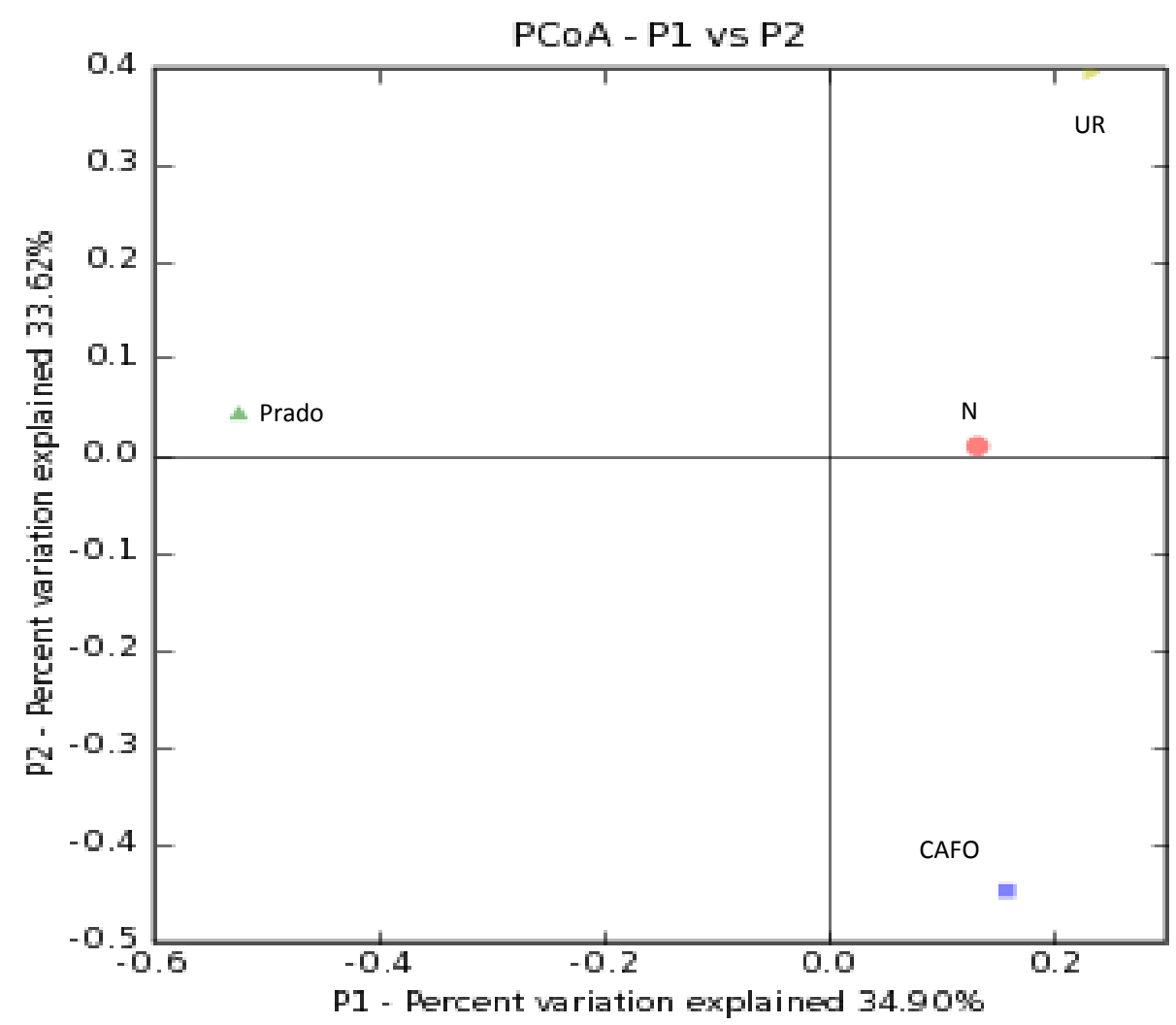

Fig. 3C: Sediment 


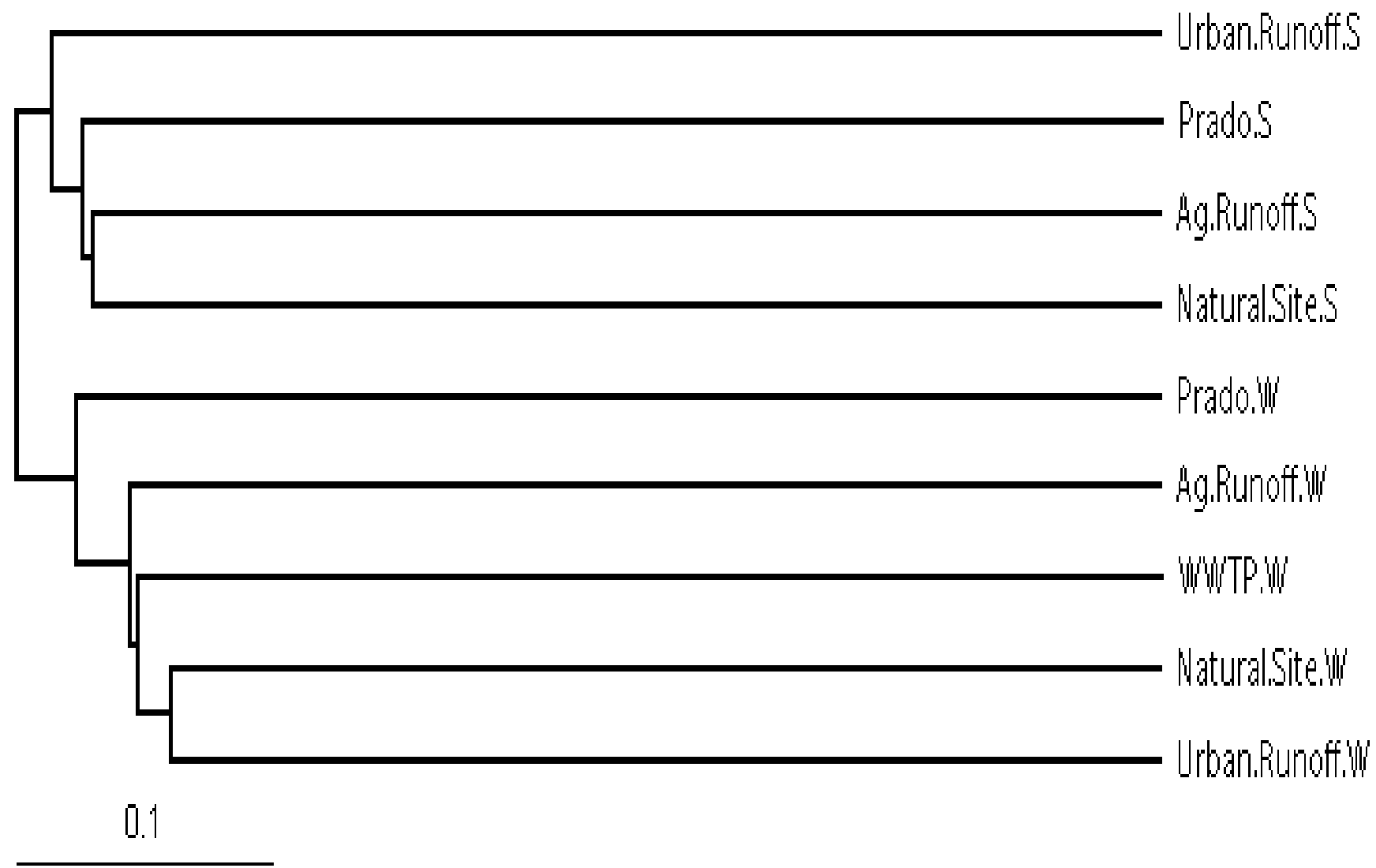

Fig. 3D: Cluster analysis of normalized jackknife (1000 permutations) of pyrosequencing data 


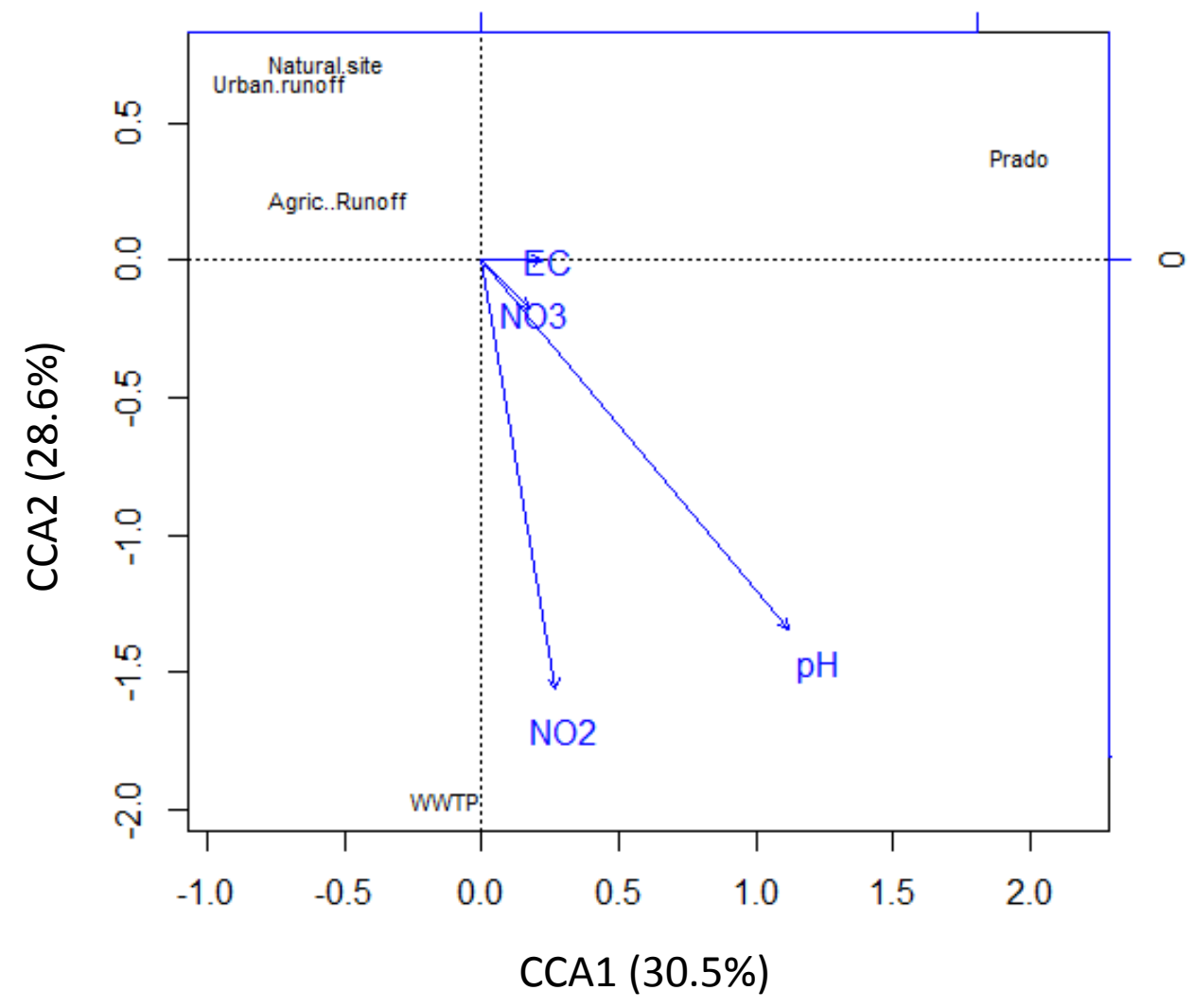

Fig. 4A: water 


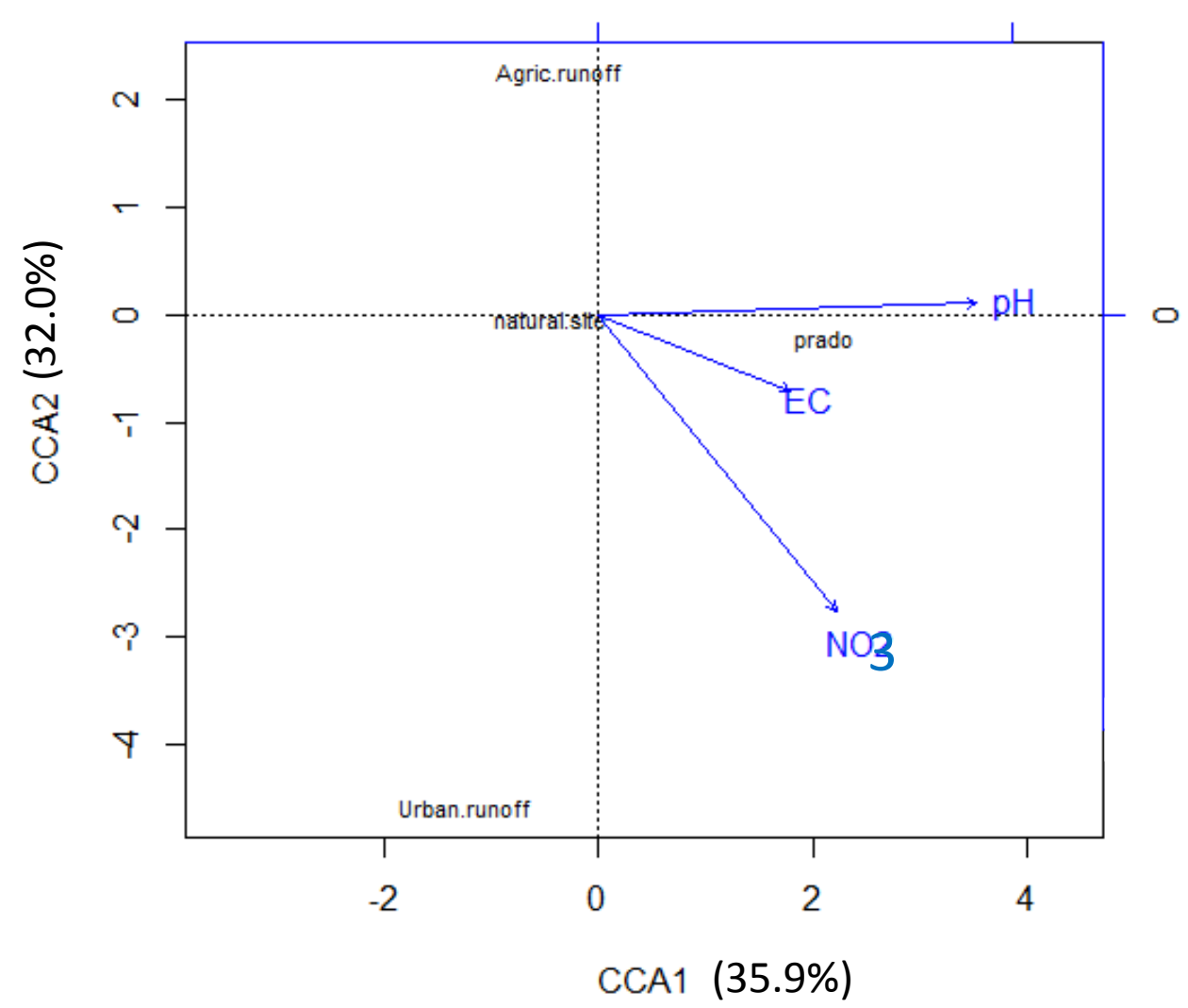

Fig. 4B sediment 


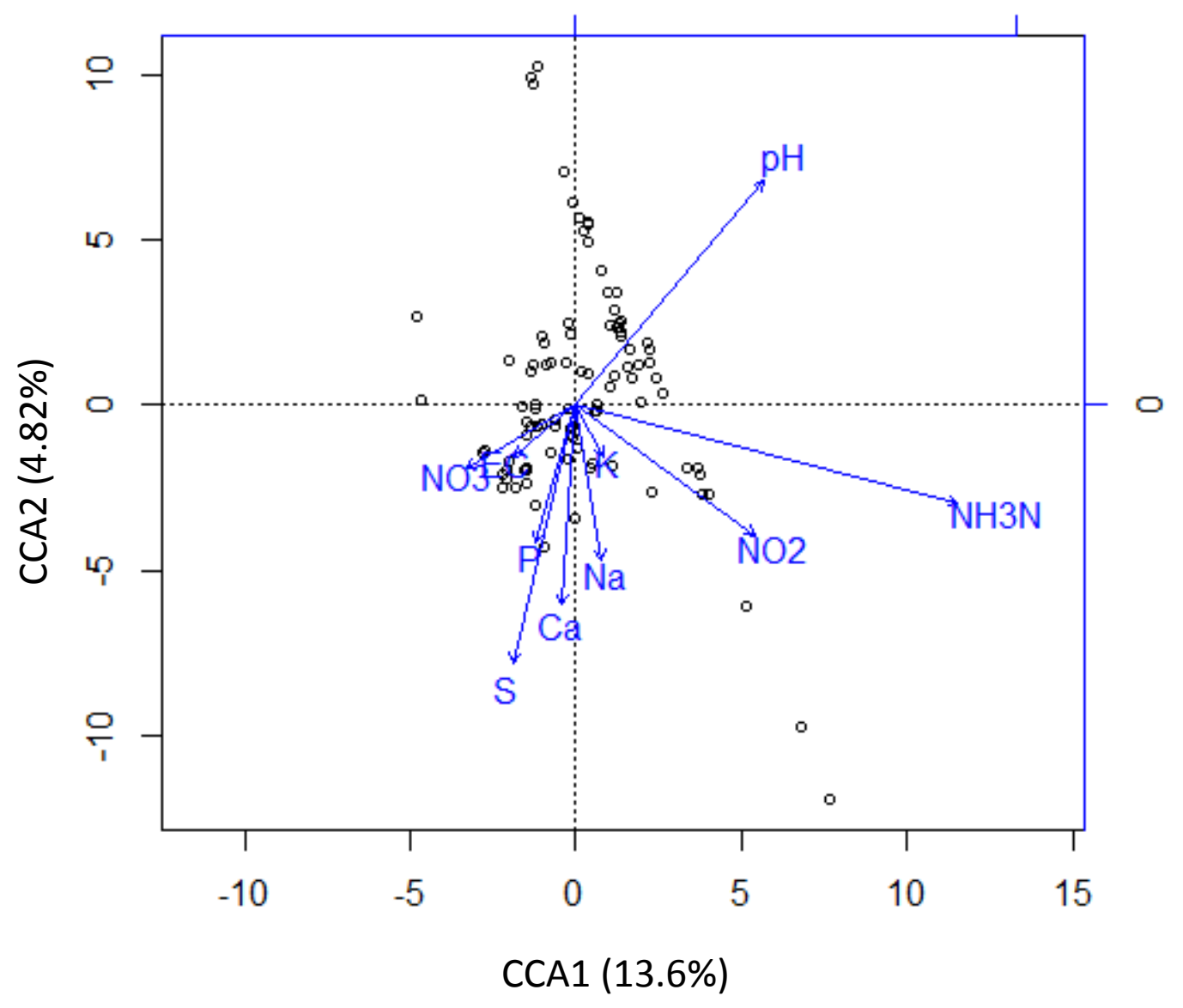

Fig. 5A. Water property vs pathogen 


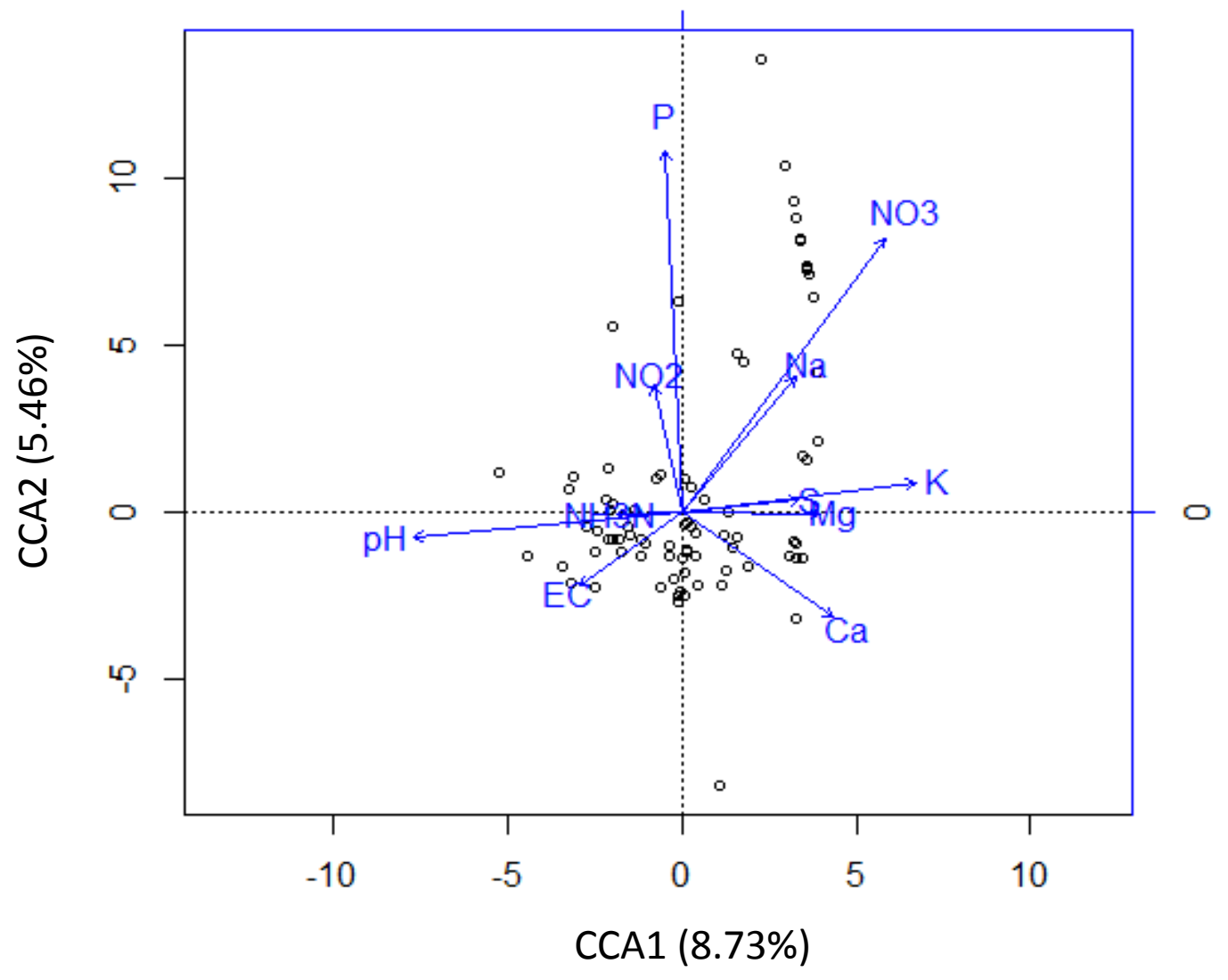

Fig. 5B. Sediment property vs Sediment pathogen 


\section{Natural site}
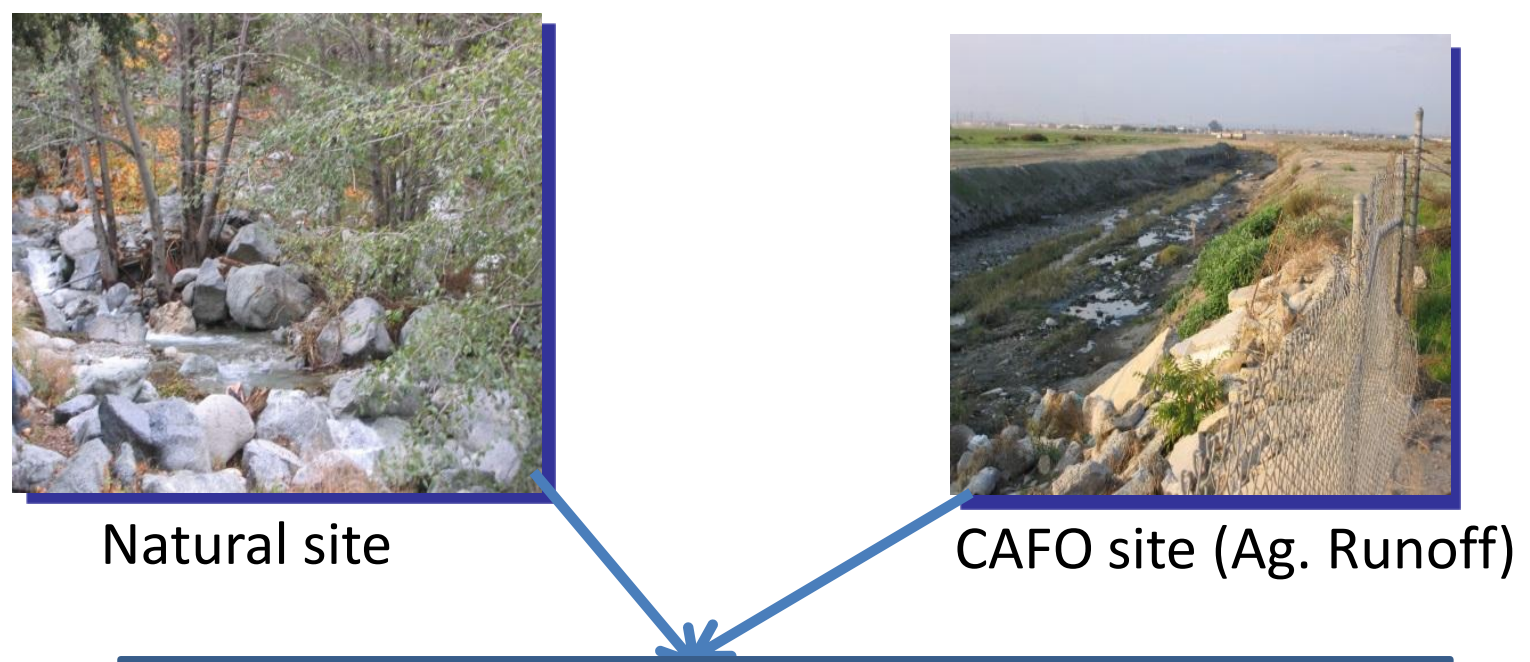

DNA extraction from sediment and water samples

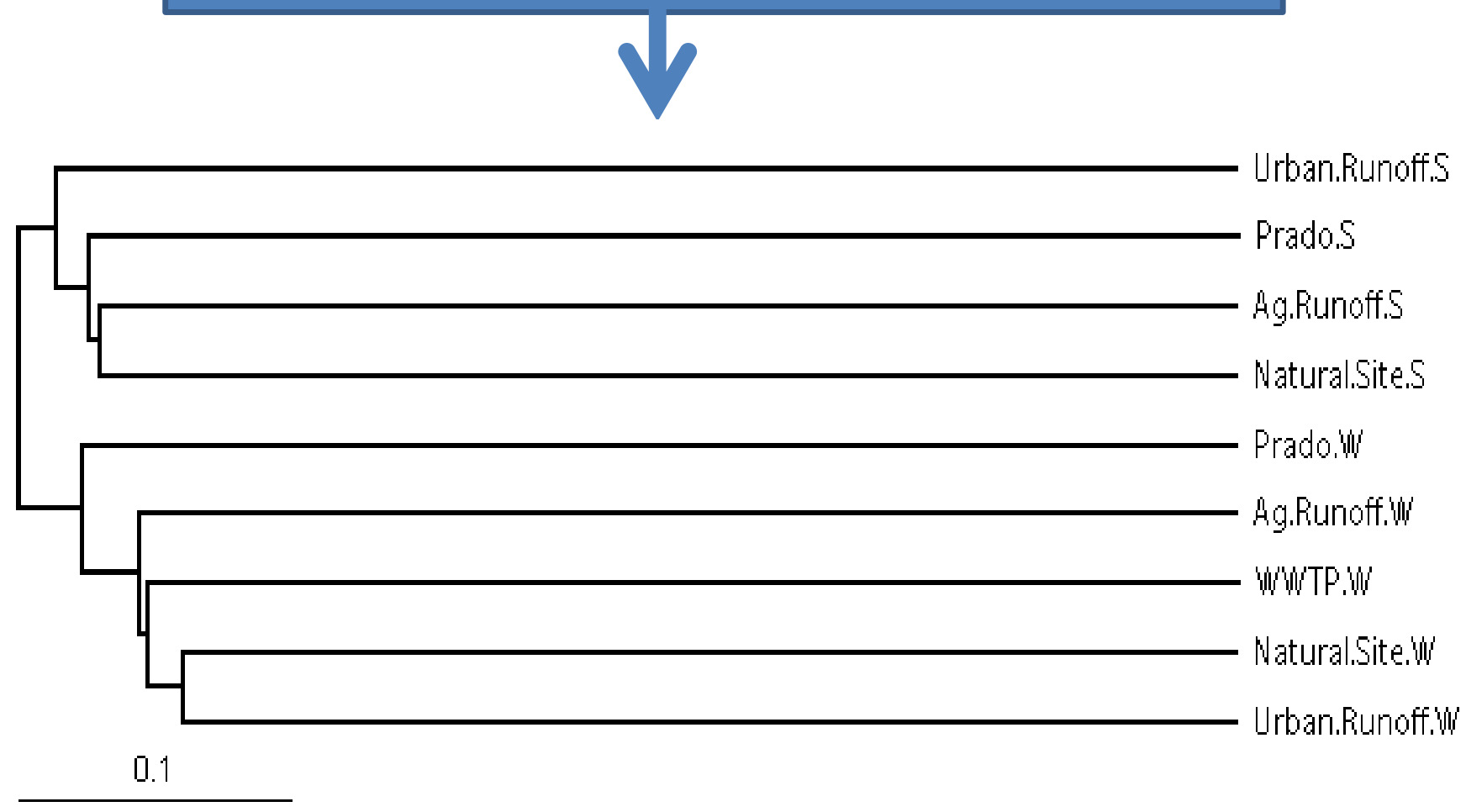

Cluster analysis of normalized jackknife (1000 permutations) of pyrosequencing data 